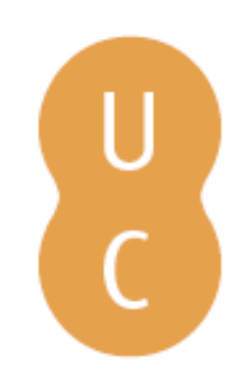

\title{
pommalina
}

\section{Trainability of VO2max during childhood and adolescence}

Autor(es): $\quad$ Helmantel, Adriaan J.; Elferink-Gemser, Marije T.; Visscher, Chris

Publicado por: Imprensa da Universidade de Coimbra

URL

persistente:

URI:http://hdl.handle.net/10316.2/38873

DOI:

DOI:http://dx.doi.org/10.14195/978-989-26-1171-6_10

Accessed : $\quad$ 26-Apr-2023 12:30:28

A navegação consulta e descarregamento dos títulos inseridos nas Bibliotecas Digitais UC Digitalis, UC Pombalina e UC Impactum, pressupõem a aceitação plena e sem reservas dos Termos e Condições de Uso destas Bibliotecas Digitais, disponíveis em https://digitalis.uc.pt/pt-pt/termos.

Conforme exposto nos referidos Termos e Condições de Uso, o descarregamento de títulos de acesso restrito requer uma licença válida de autorização devendo o utilizador aceder ao(s) documento(s) a partir de um endereço de IP da instituição detentora da supramencionada licença.

Ao utilizador é apenas permitido o descarregamento para uso pessoal, pelo que o emprego do(s) título(s) descarregado(s) para outro fim, designadamente comercial, carece de autorização do respetivo autor ou editor da obra.

Na medida em que todas as obras da UC Digitalis se encontram protegidas pelo Código do Direito de Autor e Direitos Conexos e demais legislação aplicável, toda a cópia, parcial ou total, deste documento, nos casos em que é legalmente admitida, deverá conter ou fazer-se acompanhar por este aviso. 

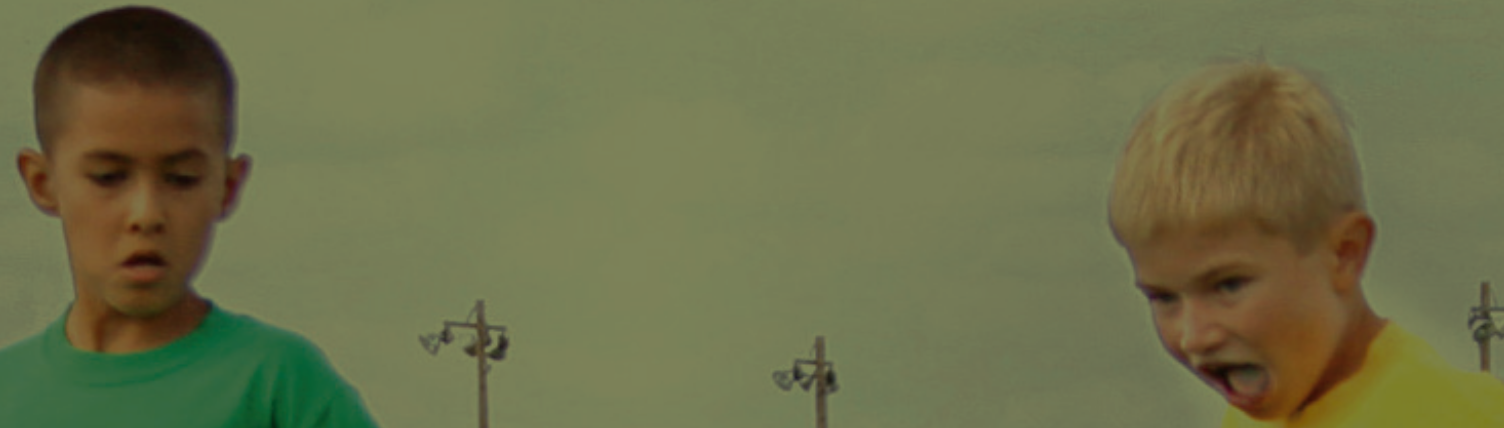

YOUTH SPORTS

\section{PARTICIPATION, $:$}

TRAINABHLTY TY

AND READINESSh

MANUEL J. COELHO E SILVA

ANTÓNIO J. FIGUEIREDO

MARIJE T. ELFERINK-GEMSER

ROBERT M. MALINA

EDITORS

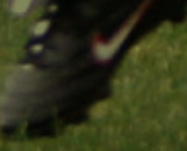

2. ${ }^{\circ}$ EDIÇÃO

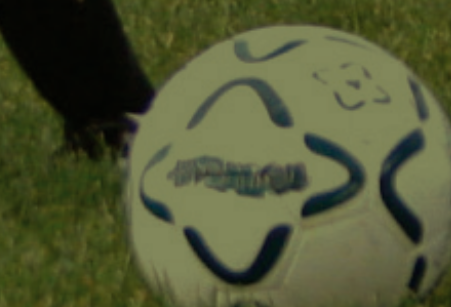

IMPRENSA DA

UNIVERSIDADE

DE COIMBRA

COIMBRA

UNIVERSITY

PRESS 


\title{
CHAPTER I0: TRAINABILITY OF VO $\max$ DURING CHILDHOOD AND ADOLESCENCE
}

\author{
Adriaan J Helmantel \\ Marije T Elferink-Gemser \\ Chris Visscher
}

\section{INTRODUCTION}

$\mathrm{VO}_{2}$ max develops just like other processes related to growth and maturation during childhood and adolescence. Longitudinal studies show an increase of absolute and relative $\mathrm{VO}_{2} \max$. Absolute $\mathrm{VO}_{2}$ max of untrained children and adolescents increases from about $1.0 \mathrm{l} / \mathrm{min}$ at the age of 6 to 2.0 and $2.8 \mathrm{l} / \mathrm{min}$ at the age of 15 for girls and boys, respectively. After this age, improvement of untrained boys continues, while $\mathrm{VO}_{2}$ max of untrained girls reaches a plateau (Krahenbuhl et al., 1985). VO2max relative to body mass shows a different pattern in untrained children. It improves in boys and girls until about 10 years; subsequently, $\mathrm{VO}_{2} \max$ remains at a plateau in boys and declines in girls (Krahenbuhl et al., 1985; Bar-Or, 1986; Rowland, 1996).

Although $\mathrm{VO}_{2}$ max is partly determined by genotype, it can be improved with systematic training it is also trainable. Much research has been done with adults and improvements up to 30\% have been recorded (Powers and Howley, 2003). The responsiveness of $\mathrm{VO}_{2}$ max to training is also partly determined by genotype (Bouchard et al., 1997). In contrast to adults, less research has been conducted on the responsiveness of $\mathrm{VO}_{2} \max$ to training in children and adoescents. The available research also shows variation in results (Baquet et al., 2003; Thompson and Baxter-Jones, 2002), ranging from no significant changes (e.g., Gilliam and Freedson, 1980) to improvements reaching 15\% (e.g., Stansky et al., 1979).

The focus of this review is the trainability of $\mathrm{VO}_{2} \max$ in children and adolescents. The review is set within the context of three stages of sport development that characterize childhood and adolescence (Côté and Hay, 2002) which are set within the deliberate practice model of expertise (Ericsson, 2003; Ericsson et al., 1993). The first stage covers the sampling years (6-12) during which there is high frequency of deliberate play and a low frequency of deliberate practice. The second stage is the specializing years (1315) which are characterized by similar amounts of deliberate play and deliberate practice. The third stage, the investment years $(16+)$ is dominated 
by deliberate practice with low frequency of deliberate play. Relevant questions are the following: Are changes in $\mathrm{VO}_{2}$ max due only to growth and maturation or are they also due to training? Do changes in $\mathrm{VO}_{2}$ max occur in each of the sport developmental stages? What is the magnitude of change in $\mathrm{VO}_{2} \mathrm{max}$ in each of the stages?

\section{METHODS}

The focus of this review is literature over the past 15 years (since 1993). Articles were collected by means of computer search through relevant data bases (Web of Science, PubMed, and Google Beta). The search items were as

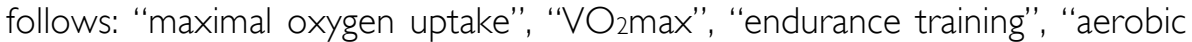
training", "anaerobic training" "effects of training", "physical training", "trainability" and "cardiovascular system". The results were then refined for "children", "adolescents", "young athletes", "youth", "teenagers", "pubertal" and "prepubertal". Articles were selected based on abstract reading. Only studies of healthy, non-obese children and adoscents were included.

Selected articles were reviewed with a focus on the following: number of participants and sex, chronological age, characteristics of the training intervention (content, duration, intensity, frequency, length), presence or absence of control group, absolute and/or relative values for $\mathrm{VO}_{2} \mathrm{max}$ at the beginning and end of the training program, percentage change and significance of the change.

$\mathrm{VO}_{2}$ max is the most commonly used term for maximal achieved oxygen uptake. However, $\mathrm{VO}_{2}$ max in children and adolescents is characterized by a plateau and a real maximal value is not always attained. The highest level of $\mathrm{VO}_{2}$ is used is expressed as peak $\mathrm{VO}_{2}$. Although peak $\mathrm{VO}_{2}$ is generally treated as equivalent to $\mathrm{VO}_{2} \mathrm{max}$ in children and adolescents (Rowland 1993), the term $\mathrm{VO}_{2}$ max is used in this review.

\section{RESULTS}

\section{$\mathrm{VO}_{2} \mathrm{max}$ without a training intervention}

Studies of $\mathrm{VO}_{2} \max$ without a training intervention in children and adolescents are summarized in Table I. Studies of $\mathrm{VO}_{2} \max$ of trained and untrained children and adolescents should be noted. Untrained youth generally show lower levels of $\mathrm{VO}_{2} \max$ compared to trained youth with relative values ranging from 35.2 to $48.0 \mathrm{ml} / \mathrm{kg} / \mathrm{min}$ in boys and from 35.8 to $41.7 \mathrm{ml} / \mathrm{kg} / \mathrm{min}$ 
in girls. Absolute $\mathrm{VO}_{2} \max$ for untrained boys and girls 9 to 16 years are also lower (Dencker et al., 2006, 2007; Gursel et al., 2004; Impertone et al., 2006; Pate et al., 2007; Rowland et al., 2000; Vinet et al., 2003). Two studies investigated relative $\mathrm{VO}_{2}$ max across several age-categories spanning childhood and adolescence. Between 5 and 13 years of age, relative $\mathrm{VO}_{2}$ max increased by $36 \%$ in boys and by only $10 \%$ in girls (Gursel et al., 2004), while between 12 and 19 years, relative $\mathrm{VO}_{2}$ max increased by $6.7 \%$ in boys and decreased by $5.5 \%$ in girls (Pate et al., 2007).

Trained boys 10 to 18 years generally show a relative $\mathrm{VO}_{2} \mathrm{max}$ between 50 and $70 \mathrm{ml} / \mathrm{kg} / \mathrm{min}$ (Cleuziou et al., 2002; Cubero et al., 2000; Eisenman et al., 200 I; Noury et al., 2004; Thevenet et al., 2007; Tolfrey et al., 2006). Only study of trained boys reported a relative $\mathrm{VO}_{2} \max <50 \mathrm{ml} / \mathrm{kg} / \mathrm{min}$ (Cubero et al., 2000). In this study, 17 year old male soccer player had a mean relative $\mathrm{VO}_{2} \mathrm{max}$ of $48.0 \mathrm{ml} / \mathrm{kg} / \mathrm{min}$, whereas cyclists and canoeists had, respectively, values of 57.0 and $53.0 \mathrm{ml} / \mathrm{kg} / \mathrm{min}$. The highest relative $\mathrm{VO}_{2} \mathrm{max}$ in boys was observed in 17 year old elite distance runners, $67.5 \mathrm{ml} / \mathrm{kg} / \mathrm{min}$ (Eisenmann et al., 200 I). Girls in the latter study had relative $\mathrm{VO}_{2}$ max of $\sim 55$ $\mathrm{ml} / \mathrm{kg} / \mathrm{min}$, which was considerably higher than $40.2 \mathrm{ml} / \mathrm{kg} / \mathrm{min}$ in trained prepubertal children (Noury et al., 2004).

Only a few studies report absolute $\mathrm{VO}_{2}$ max in trained children and adolescents. Levels up to $2.50 \mathrm{l} / \mathrm{min}$ were reported in boys up to about 12 years which increased to $4.39 \mathrm{l} / \mathrm{min}$ in boys 18 years of age. Girls show levels of 1.31 to $2.28 \mathrm{l} / \mathrm{min}$ to about 12 years and of $2.89 \mathrm{l} / \mathrm{min}$ at 17 years (Eisenman et al., 200 I; Noury et al., 2004; Tolfrey et al., 2006).

\section{$\mathrm{VO}_{2}$ max values with a training intervention}

a) Sampling years (about 6-12 years)

An overview of results are reported in Table 2. Given the variation in study designs and protocols, it is most effective to consider studies separately.

In a study of 14 prepubertal girls, 5 ( $9.3 \pm 0.5$ years) participated in a swim training program of about one year duration whereas the control group of 9 girls (9.3 \pm 0.4$)$ had no additional training (Obert et al., 1996). The experimental group trained 5 times per week for 2 hours, spread over 2 sessions a day. Training consisted of various activities to improve swimming technique and physiological capacity. All girls were tested on a swim ergometer (only arms involved) at the beginning and after one year. Both experimental and control groups increased significantly in absolute $\mathrm{VO}_{2}$ max by 
$39 \%$ and $13 \%$, respectively, from $0.79 \pm 0.12$ to $1.10 \pm 0.17 \mathrm{l} / \mathrm{min}$ and from $0.69 \pm 0.10$ to $0.78 \pm 0.12 \mathrm{l} / \mathrm{min}$. The experimental group showed significant improvement of relative $\mathrm{VO}_{2} \max$ from $26.2 \pm 4.4$ to $33.8 \pm 5.0 \mathrm{ml} / \mathrm{kg} / \mathrm{min}$ $(+29 \%)$ while that of the control group remained stable at about 24.7 $\mathrm{ml} / \mathrm{kg} / \mathrm{min}$.

Thirty-eight boys, 11.5 years of age, participated in a sport-specific training study over 18 months (Vamvakoudis et al., 2007). Of this group, 20 boys formed The experimental group $(n=20)$ had 2 years of basketball experience while the control group $(n=18)$ had no sport experience and participated in normal physical education at school, 2 or 3 times a week for 40 minutes during the course of the study. The experimental group had 6 mixed basketball-related training sessions of different intensities per week each 90 minutes in duration. The boys were tested every 6 months with an incremental treadmill running test. The experimental group had significantly higher absolute and relative $\mathrm{VO}_{2} \mathrm{max}$ at the beginning and end of the training period. Both the control and experimental groups improved significantly in absolute $\mathrm{VO}_{2}$ max. The control group increased in absolute $\mathrm{VO}_{2} \max$ by $24.2 \%$ from $2.11 \pm 0.34$ to $2.62 \pm 0.30 \mathrm{l} / \mathrm{min}$ and in relative values by $8.1 \%$ from $42.2 \pm 5.3$ to $45.6 \pm 6.4 \mathrm{ml} / \mathrm{min} / \mathrm{kg}$. The experimental group improved in absolute $\mathrm{VO}_{2} \mathrm{max}$ by $34.6 \%$ from $2.3 \mathrm{I} \pm 0.4 \mathrm{I}$ to $3.1 \mathrm{I} \pm 0.50 \mathrm{I} / \mathrm{min}$ and in relative values by $8.6 \%$ from $51.4 \pm 3.9$ to $55.8 \pm 4.1 \mathrm{ml} / \mathrm{min} / \mathrm{kg}$. Of interest, the relative gain in $\mathrm{VO}_{2}$ max per unit body mass was virtually identical in the control and experimental groups, $\sim 8 \%$.

An experimental group ( 6 girls, 6 boys, $10.4 \pm 0.3$ years) trained for 13 weeks, 3 times per week for I hour. The protocol involved interval training (running at $90 \% \mathrm{HR}$ max), continuous training (running at $80 \% \mathrm{HR}$ max) and other aerobic activities including soccer, basketball and swimming (Mandigout et al., 2002). The control group (3 girls, 4 boys, $10.7 \pm 0.5$ years) participated in regular activities. $\mathrm{VO}_{2}$ max was measured with an incremental bicycle ergometer test. After 13 weeks, the experimental group increased significantly in relative $V_{2} \max , 41.3 \pm 8.3$ to $47.9 \pm 10.7 \mathrm{ml} / \mathrm{kg} / \mathrm{min}(+16.0 \%)$, while the control group showed no improvement in relative $\mathrm{VO}_{2}$ max although their mean value, $45.9 \mathrm{ml} / \mathrm{kg} / \mathrm{min}$ was rather high compared to those in the experimental training program. Unfortunately, absolute values and differences between boys and girls were not reported.

Comparable results were noted in a study 7 boys and II girls ( $10.0 \pm 0.8$ years) who were randomly divided into experimental and control groups (Noury et al., 2005). The experimental group had a training program of 8 weeks which included normal physical education lessons and the two sessions per week of 30 minutes high intensive running. The control group had normal physical education with no additional training. All children did an 
incremental test on a bicycle ergometer at the beginning and end of the study. Relative $\mathrm{VO}_{2} \max$ of the experimental group improved significantly from $37.4 \pm 7.3$ to $43.2 \pm 7.6 \mathrm{ml} / \mathrm{min} / \mathrm{kg}(+15 \%)$, while relative $V_{2} \mathrm{max}$ of the control group remained the same over the 8 weeks, $38.8 \mathrm{ml} / \mathrm{kg} / \mathrm{min}$. Unfortunately, neither absolute values nor sex differences were reported.

A sample of 19 children ( 10 girls, 9 boys) 10- I I years followed a 13week training program of continuous ( $>80 \% \mathrm{HR}$ max) and interval $(>90 \% \mathrm{HR}$ max) activities for I.0-1.5 hours per session, 3 times per week, while 16 children ( 7 girls, 9 boys) of the same age served as a control group (Obert et al., 2003). All children performed an incremental cycle ergometer test before and after the program. Relative $\mathrm{VO}_{2} \max$ increased significantly in the experimental group, $40.9 \pm 8.9$ to $44.2 \pm 8.4 \mathrm{ml} / \mathrm{min} / \mathrm{kg}$ in girls and $44.1 \pm 6.1$ to $50.9 \pm 6 . \mathrm{ml} / \mathrm{min} / \mathrm{kg}$ in boys, $8.1 \%$ and $15.4 \%$, respectively. This means an improvement of VO2-max of respectively $8.1 \%$ and $15.4 \%$. Relative $\mathrm{VO}_{2}$ max of the control group, on the other hand, did not change, 42.4 and 51.5 $\mathrm{ml} / \mathrm{kg} / \mathrm{min}$ in girls and boys, respectively, after 13 weeks. Absolute values were not reported.

Using a 7 week training program, 13 boys and 20 girls ( $9.5 \pm 0.9$ years) participated in normal physical education lessons plus 2 additional training sessions per week (Baquet et al., 2002). The latter consisted of 30 minutes of short high intermittent exercise ( 10 and 20 second sprints). Ten boys and 10 girls $(9.9 \pm 0.4$ years) comprised a control group which had only normal physical education lessons. $\mathrm{VO}_{2}$ max was estimated with a graded field running test. The experimental group improved significantly in absolute $\mathrm{VO}_{2} \mathrm{max}$, $1.54 \pm 0.35$ to $1.68 \pm 0.36 \mathrm{l} / \mathrm{min}$, and in relative $\mathrm{VO}_{2} \max , 43.9 \pm 6.2$ to $47.5 \pm 7.2$ $\mathrm{ml} / \mathrm{min} / \mathrm{kg}$ ( $+9.1 \%$ and $+8.2 \%$, respectively). The control group did not change in either absolute or relative $V_{2} \max , 1.62 \mathrm{l} / \mathrm{min}$ and $46.2 \mathrm{ml} / \mathrm{kg} / \mathrm{min}$, respectively. Sex differences were not reported.

Comparable results were obtained in a study of 40 girls $(9.1 \pm 0.1$ years) attending a summer camp (Eliakim et al., 200 I). An experimental group $(n=20)$ followed 2 training sessions of 45 minutes per day, 5 days per week over 5 weeks. The sessions consisted of endurance activities, 50\% running activities and $50 \%$ ball sports. All activities were performed as games and intensity levels were not reported. The remaining girls $(n=20)$ served as a control group who did not have special training sessions. $\mathrm{VO}_{2}$ max was measured with an incremental bicycle ergometer test. The experimental group increased significantly in relative $\mathrm{VO}_{2} \max (+9.5 \%)$. Post-training $\mathrm{VO}_{2}$ max was $1.45 \mathrm{l} / \mathrm{min}$ and $45 \mathrm{ml} / \mathrm{min} / \mathrm{kg}$ in the experimental group. Exact values, pretraining values and values for the control group were not reported.

Using a 13 weeks protocol, 17 girls (10.5 \pm 0.4 years) and 18 boys 
( $10.7 \pm 0.4$ years) trained 3 times per week in 1.0-1.5 hour sessions of interval training (90\% HR max), continuous training (75-85\% HR max) and several aerobic activities, while 22 girls ( $10.5 \pm 0.9)$ and 28 boys ( $0.5 \pm 0.5$ years) formed a control group which has no special training (Mandigout et al., 200 I). An incremental bicycle ergometer test was used. Experimental girls improved significantly in both absolute $(1.30 \pm 0.2$ to $1.57 \pm 0.2 \mathrm{l} / \mathrm{min},+20.8 \%)$ and relative $\left(38.6 \pm 4.4\right.$ to $41.9 \pm 4.6 \mathrm{ml} / \mathrm{min} / \mathrm{kg}$, +8.5\%) $\quad \mathrm{VO}_{2} \max$. Corresponding improvements in experimental boys were somewhat less but significant, $1.70 \pm 0.3$ to $1.84 \pm 0.3 \mathrm{l} / \mathrm{min}(+8.2 \%)$ in absolute and $47.2 \pm 7.9$ to $49.2 \pm 7.1 \mathrm{ml} / \mathrm{min} / \mathrm{kg}(+4.2 \%)$ in relative $\mathrm{VO}_{2}$ max. The control group also improved in absolute $\mathrm{VO}_{2 \max }$ (girls $+6.9 \%, 1.40$ to $1.50 \mathrm{l} / \mathrm{min}$, boys $+6.3 \%$, 1.60 to $170 \mathrm{l} / \mathrm{min}$ ) whereas relative $\mathrm{VO}_{2} \mathrm{max}$ did not change, $39.6 \mathrm{ml} / \mathrm{kg} / \mathrm{min}$ in girls and $46.1 \mathrm{ml} / \mathrm{kg} / \mathrm{min}$ in boys.

A similar 13 week protocol was used to compare training programs of 3 and 2 times per week in 10-11 year old children (mean ages were not reported, Mandigout et al., 2002). The first experimental group ( 8 boys, I 8 girls) did interval training ( $90 \% \mathrm{HR}$ max), continuous training (80\% HR max) and a mixed training with several aerobic activities like basketball and other games 3 times per week, while the second experimental group ( 10 boys, 10 girls) trained in the same manner but without the mixed session only 2 times a week. All training sessions lasted one hour. A control group ( 15 boys, 13 girls) were not involved in extra training activities. An incremental bicycle ergometer test was used. The first experimental group of girls increased significantly both absolute and relative $\mathrm{VO}_{2} \max$ by $14.6 \%(1.37 \pm 0.20$ to $1.57 \pm 0.19 \mathrm{l} / \mathrm{min})$ and $8.6 \%(38.2 \pm 4.4$ to $41.5 \pm 4.6 \mathrm{ml} / \mathrm{min} / \mathrm{kg})$, respectively. Boys in the first experimental group gained in absolute $\mathrm{VO}_{2} \mathrm{max}$ by $6.4 \%(\mathrm{I} .7 \mathrm{I} \pm 0.32$ to $1.82 \pm 0.39 \mathrm{l} / \mathrm{min}$ ) and in relative $\mathrm{VO}_{2} \max$ by $5.1 \%(46.9 \pm 7.9$ to $49.3 \pm 7.1$ $\mathrm{ml} / \mathrm{min} / \mathrm{kg}$ ). Children in the second experimental group made smaller gains in absolute $\mathrm{VO}_{2}$ max, $+4.2 \%$ in girls $(1.44$ to $1.50 \mathrm{l} / \mathrm{min})$ and $+2.4 \%$ in boys $(1.66$ to $1.70 \mathrm{l} / \mathrm{min}$ ); relative $\mathrm{VO}_{2}$ max improved only in girls, $+1.2 \%$ (40.I to 40.6 $\mathrm{ml} / \mathrm{kg} / \mathrm{min}$ ) but not in boys (stable at $45.5 \mathrm{ml} / \mathrm{kg} / \mathrm{min}$ ). The control group also improved in absolute $\mathrm{VO}_{2}$ max, $+6.9 \%$ in girls $(1.45$ to $1.55 \mathrm{l} / \mathrm{min})$ and $+1.8 \%$ in boys ( 1.69 to $1.72 \mathrm{l} / \mathrm{min}$ ), while relative $\mathrm{VO}_{2}$ max did not change, girls $4 \mathrm{I} .1$ $\mathrm{ml} / \mathrm{kg} / \mathrm{min}$ and boys $46.6 \mathrm{ml} / \mathrm{kg} / \mathrm{min}$.

In contrast to the preceding studies which utilized a variety of activities to make training more attractive, others have utilized a more controlled training protocol (McManus et al., 1997, 2005). VO2max of boys in continuous $(n=10,10.4 \pm 0.5$ years) and interval $(n=10,10.4 \pm 0.3$ years) training groups and a control group ( $\mathrm{n}=15$ boys, $10.5 \pm 0.4$ years) were compared after 8 weeks. Both experimental groups trained 3 times per week for 20 minutes, while the control group had no training. The continuous training protocol involved 20 minutes per session on a cycle ergometer at heart rate between 
160 and $170 \mathrm{bpm}$, while the interval training protocol called for 7 maximal sprints of 30 seconds each during the 20 minute session. Boys rested between sprints by cycling at low speed. After 8 weeks, both training groups increased significantly in $\mathrm{VO}_{2} \max$ on an incremental bicycle ergometer test. Best results were achieved by the interval training group. Absolute $\mathrm{VO}_{2} \mathrm{max}$ increased by $11.4 \%(1.76 \pm 0.20$ to $1.96 \pm 0.22 \mathrm{l} / \mathrm{min})$ and relative $\mathrm{VO}_{2} \mathrm{max}$ increased by I I.4\% (45.5 \pm 3.4 to $50.7 \pm 3.7 \mathrm{ml} / \mathrm{min} / \mathrm{kg})$. The continuous training group had smaller gains in absolute and relative $\mathrm{VO}_{2} \max$, respectively, $1.65 \pm 0.16$ to $1.72 \pm 0.17 \mathrm{l} / \mathrm{min}(4.2 \%)$ and $47.0 \pm 6.5$ to $50.7 \pm 6.9 \mathrm{ml} / \mathrm{min} / \mathrm{kg}(7.9 \%)$. The control group, in contrast, improved in relative $\mathrm{VO}_{2}$ max by $1.6 \%$ (44.7 to 45.4 $\mathrm{ml} / \mathrm{kg} / \mathrm{min}$ ), while absolute $\mathrm{VO}_{2}$ max remained rather stable at $1.59 \mathrm{l} / \mathrm{min}$ after 8 weeks.

The second study included 12 girls ( $9.3 \pm 0.5$ years) who participated in a cycle ergoment training protocol 3 times per week for 20 minutes at a heart rate of 160 to $170 \mathrm{bpm}$ and II girls $(9.8 \pm 0.4)$ who participated in sprint running for 8 weeks. The running protocol called for maximal sprints of 10 and 30 seconds; the number of sprints increased from 3 of each duration in the first week to 6 sprints of each duration in week 8 (McManus et al., 1997). A control group had no formal training. $\mathrm{VO}_{2}$ max was assessed with aan incremental treadmill test. Both experimental groups improved significantly in absolute $\mathrm{VO}_{2}$ max, cycling group by $10 \%(1.30 \pm 0.19$ to $1.43 \pm 0.20 \mathrm{l} / \mathrm{min})$ and running group by $8.4 \%$ ( $1.54 \pm 0.24$ to $1.67 \pm 0.22)$, while the control group did not change in absolute $\mathrm{VO}_{2} \mathrm{max}(\mathrm{I} .49 \mathrm{l} / \mathrm{min})$ after 8 weeks.

Also using a laboratory protocol, an experimental group ( 12 boys, 14 girls) trained for 12 weeks on 3 sessions per week of 30 minutes continuous (80\% of HR max) cycling on an ergometer (Tolfrey et al., 1998). A control group ( 10 boys, 9 girls) had no additional training. Mean age of the total group was $10.5 \pm 0.7$ years. An incremental cycling test was used to estimate $\mathrm{VO}_{2}$ max. The experimental group increased absolute $\mathrm{VO}_{2}$ max by $3.8 \%$ in boys $(1.60$ to $1.66 \mathrm{l} / \mathrm{min}$ ) and $13.2 \%$ in girls ( 1.36 to $1.54 \mathrm{l} / \mathrm{min}$ ); variance statistics were not reported. Relative $\mathrm{VO}_{2}$ max increased by $1.3 \%$ in boys (46.6 to $47.2 \mathrm{ml} / \mathrm{kg} / \mathrm{min}$ ) and $7.9 \%$ in girls $(39.3$ to $42.4 \mathrm{ml} / \mathrm{kg} / \mathrm{min})$. Although there was a trend for improved performance, the changes were not significant. The control group did not change in relative $\mathrm{VO}_{2} \max , 44.7 \mathrm{ml} / \mathrm{kg} / \mathrm{min}$ in girls and $50.7 \mathrm{ml} / \mathrm{kg} / \mathrm{min}$ in boys, after 12 weeks, while absolute $\mathrm{VO}_{2} \mathrm{max}$ increased slightly in boys, 1.62 to $1.65 \mathrm{l} / \mathrm{min}(+1.9 \%)$ but not in girls, $1.52 \mathrm{l} / \mathrm{min}$.

Several studies did not include a control group. To deal with this problem, subjects were followed for a period of no formal training prior to the onset of a training protocol. For example, 37 youth II-13 years of age (24 girls, 13 boys) were followed for 12 weeks before training began; subsequently, trained for 12 weeks, 3 sessions per week on an aerobic circuit, 
running and training with various ball sports (Rowland and Boyajian, 1995). Training was targeted at a heart rate between 165 and 175 bpm. Subjects were tested at the three time points with an incremental treadmill protocol. There was little change in both absolute $(1.96 \pm 0.32$ to $2.02 \pm 0.35,+3.6 \%)$ and relative $(44.3 \pm 5.8$ to $44.7 \pm 5.8 \mathrm{l} / \mathrm{min} / \mathrm{kg},+0.9 \%) \vee O_{2 m a x}$ after 12 weeks of non-training. After 12 weeks of aerobic training absolute and relative $\mathrm{VO}_{2}$ max increased significantly to $2.24 \pm 0.38 \mathrm{l} / \mathrm{min}(+10.9 \%)$ and $47.6 \pm 6.4 \mathrm{ml} / \mathrm{min} / \mathrm{kg}$ $(+6.5 \%)$. Sex-specific results were not reported.

In related study (Rowland et al., 1996), 3 I children (20 girls, 9 boys, $11.8 \pm 0.5$ years) had a baseline period of no formal training for 13 weeks (except for formal physical education 2 times per week) which was followed by 13 weeks of aerobic training which replaced the physical education classes. Training occurred 3 times per week for 30 minutes and involved several aerobic exercises (HR 170 to $180 \mathrm{bpm}$ ). An incremental cycle ergometer test was used to estimate $\mathrm{VO}_{2} \mathrm{max}$ at the three time points. Among girls absolute $V O_{2 m a x}$ increased from $1.76 \pm 0.24$ to $1.81 \pm 0.28$ to $1.97 \pm 0.34$ across the three testing moments while relative $\mathrm{VO}_{2}$ max changed only slightly, $43.7 \pm 6.3$ to $43.9 \pm 6.8$ to $46.1 \pm 7.7 \mathrm{ml} / \mathrm{kg} / \mathrm{min}$. After 13 weeks of aerobic training, absolute and relative $\mathrm{VO}_{2} \mathrm{max}$ improved by $8.8 \%$ and $5.0 \%$, respectively. Corresponding values in boys at the three testing moments were, respectively, were $2.08 \pm 0.31,2.15 \pm 0.31$ and $2.29 \pm 0.30 \mathrm{l} / \mathrm{min}$ for absolute $\mathrm{VO}_{2} \max$ and $45.3 \pm 9.2, \quad 45.4 \pm 8.8$ and $48.2 \pm 9.4 \mathrm{ml} / \mathrm{kg} / \mathrm{min}$ for relative $\mathrm{VO}_{2} \mathrm{max}$. Improvements after 13 weeks of training approcimated $6.5 \%$ and $6.2 \%$, respectively. A significance $(p=0.06)$ for for relative $\mathrm{VO}_{2}$ max is girls and boys combined was reported.

While most studies indicate an improvement in $\mathrm{VO}_{2}$ max with training, there are exceptions. An 8 week program of interval run training of 10 and 30 second maximal sprints ( 12 boys, $10.1 \pm 0.3$ years) and continuous cycling for 20 minutes at 160-170 bpm ( 13 boys, 10.1 \pm 0.2 years), 3 sessions per week resulted in no significant changes in $\mathrm{VO}_{2} \max$ (Williams et al., 2000). A control group ( 14 boys, $10.1 \pm 0.3$ years) had no training. $V O_{2 m a x}$ was measured with an treadmill incremental test. Absolute $\mathrm{VO}_{2}$ max showed a non-significant increase ( $1.84 \pm 0.2$ to $1.91 \pm 0.3 \mathrm{l} / \mathrm{min}$, +3.8\%) while relative $\mathrm{VO}_{2} \mathrm{max}$ decreased slightly $(54.8 \pm 5.1$ to $53.9 \pm 7.8 \mathrm{ml} / \mathrm{min} / \mathrm{kg},-1.6 \%)$ in the sprint interval running group. The continuous group improved, though not significantly, in both absolute $(1.80 \pm 0.3$ to $1.93 \pm 0.3 \mathrm{l} / \mathrm{min},+7.2 \%)$ and relative $(54.7 \pm 9.7$ to $57.5 \pm 7.0 \mathrm{ml} / \mathrm{min} / \mathrm{kg},+5.1 \%) \mathrm{VO}_{2} \mathrm{max}$. The control group showed a small gain in absolute $\mathrm{VO}_{2} \max (1.92 \pm 0.2$ to $\left.1.97 \pm 0.2) \mathrm{l} / \mathrm{min},+2.6 \%\right)$ but no change in relative $\mathrm{VO}_{2} \max (56.4 \mathrm{~m} / \mathrm{kg} / \mathrm{min})$. 


\section{b) Specializing years (about 13-15 years)}

Most studies of the sampling years did not use samples of not specifically trained children. investigated The influence of a 4-week training pre-season program on $\mathrm{VO}_{2}$ max was evaluated in 27 top basketball players ( $14.7 \pm 0.5$ years) divided into control $(n=7)$, specialized training $(n=10)$ and mixed training $(n=10)$ groups (Bogdanis et al., 2007). The control group did not follow any training. The specialized group followed normal basketball training of variable intensities while the mixed group combined circuit training (20\% of time) normal basketball training. Training sessions of $110-120$ minutes occurred 5 days per week. An incremental treadmill test was used. Both experimental groups showed significant improvement in relative $\mathrm{VO}_{2}$ max; absolute values were not reported. Improvements were $4.6 \%$ in both groups, $52.3 \pm \mathrm{I}$. to $54.7 \pm 0.7 \mathrm{ml} / \mathrm{kg} / \mathrm{min}$ for the specialized and $52.5 \pm 1.3$ to $54.9 \pm 1.0 \mathrm{ml} / \mathrm{kg} / \mathrm{min}$ for the mixed training protocols. The control group did not improve $(49.8 \mathrm{ml} / \mathrm{kg} / \mathrm{min})$.

Two other studies in specialization age range did not observe significant training effects. Stoedefalke et al. (2000) found no significant increase in VO2-max measured during an incremental treadmill test after 20 weeks of training. In this experiment 38 girls were involved, Twenty girls ( $13.6 \pm 0.3$ years) completed a training program of 3 sessions per week for 20 weeks (Stoedefalke et al., 2000). Training sessions were 20 minutes at $80 \%$ $\mathrm{HR}$ max and consisted of running, cycling, rowing and dancing. A group of 18 girls ( $13.7 \pm 0.2$ years) served as a control and continued normal daily activities. Absolute $\mathrm{VO}_{2}$ max increased in the experimental group by $3.1 \%, 2.25 \pm 0.30$ to $2.32 \pm 0.28 \mathrm{l} / \mathrm{min}$, while the control group improved by $2.5 \%, 2.39 \pm 0.36$ to $2.45 \pm 0.30 \mathrm{l} / \mathrm{min}$; relative values were not reported.

In a co-twin control study of 9 male monozygotic twins I|- 14 years, one twin did high speed running for 1.0-1.5 hours per session 3 days per week for 26 weeks while the other twin continued normal daily activities (Danis et al., 2002). VO2max was tested on 3 occasions with an incremental treadmill test at the beginning, after 3 months and at the end 26 weeks. Both experimental and control twins improved in absolute and relative $\mathrm{VO}_{2}$ max. Mid-way in the program ( 13 weeks), the trained twins improved in both absolute $(2.08 \pm 0.43$ to $2.23 \pm 0.45 \mathrm{l} / \mathrm{min},+7.2 \%)$ and relative $(52.1 \pm 3.6$ to $53.9 \pm 3.8 \mathrm{ml} / \mathrm{min} / \mathrm{kg},+3.5 \%) \mathrm{VO}_{2} \max$, while the control twins increased in absolute but decreased in relative $\mathrm{VO}_{2}$ max. After 26 weeks, absolute $\mathrm{VO}_{2}$ max reached $2.37 \pm 0.45 \mathrm{l} / \mathrm{min}$ and $57.5 \pm 3.6 \mathrm{ml} / \mathrm{min} / \mathrm{kg}$ in the experimental twins, reflecting further improvements of $6.3 \%$ and $6.7 \%$ in absolute and relative $\mathrm{VO}_{2}$ max, respectively. The overall improvement over 26 weeks was thus $13.9 \%$ in absolute and $10.4 \%$ in relative $\mathrm{VO}_{2}$ max. After 13 weeks, the control twins increased in absolute $(2.10 \pm 0.41$ to $2.18 \pm 0.43 \mathrm{l} / \mathrm{min},+3.8 \%)$ but 
decreased in relative $\mathrm{VO}_{2} \max (54.0 \pm 3.9$ to $52.6 \pm 3.8 \mathrm{ml} / \mathrm{min} / \mathrm{kg},-2.6 \%$ ). Over the next 13 weeks, absolute $\mathrm{VO}_{2}$ max increased to $2.32 \pm 0.47 \mathrm{l} / \mathrm{min}$ $(+6.4 \%)$ and relative $\mathrm{VO}_{2} \mathrm{max}$ increased to $55.4 \pm 3.3 \mathrm{ml} / \mathrm{min} / \mathrm{kg}(+5.3 \%)$ in the control twins. The control twins increased by $10.5 \%$ in absolute and by $2.6 \%$ in relative $\mathrm{VO}_{2}$ max over the 26 week interval. Mid-way during the program, improvements in $\mathrm{VO}_{2}$ max between experimental and control twins were significant but after 26 weeks they were not.

c) Investment years (about 16-18 years)

Eliakim et al. (1996) also investigated effects of training in 15-17 (no means were reported) years old girls. A summer school setting was used to evaluate the influence of an aerobic training program on girls 15-17 years of age (Eliakim et al., 1996). A sample of 44 girls were randomly dived into experimental and control groups. The former had 5, two hour training sessions per week for 5 weeks; sessions included 50\% running, 25\% team sports and 25\% dancing (although no further specifics were indicated). Control subjects had no special activities other than a computer education program. An incremental cycle test was used. Experimental subjects significantly improved in absolute $\mathrm{VO}_{2}$ max by $12.1 \%, 1.48 \pm 0.6$ to $1.63 \pm 0.5 \mathrm{l} / \mathrm{min}$, whereas control subjects showed no change $(1.57 \mathrm{l} / \mathrm{min})$. Relative values were not reported.

$\mathrm{VO}_{2} \mathrm{max}$ was measured before and after a competitive season ( 13 weeks) in a team of 9 male cross country runners ( $15.9 \pm 1.0$ years, $4.2 \pm 2.1$ years of experience) using an incremental test on a running ergometer (Plank et al., 2005). Training consisted of 6 sessions a week of about I hour duration using different running activities (continuous and interval running, competitive races. Both absolute and relative $\mathrm{VO}_{2} \mathrm{max}$ increased significantly after 13 weeks, $3.73 \pm 0.64$ to $3.98 \pm 0.62 \mathrm{l} / \mathrm{min}(+6.7 \%)$ and $61.6 \pm 3.5$ to $65.3 \pm 2.9$ $\mathrm{ml} / \mathrm{min} / \mathrm{kg}(+6.0 \%)$. No control group was included.

A sample of 16 late adolescent-young adults (4 boys, 12 girls, $19.5 \pm 3.2$ years) was included in a study comparing measurements of the CardioCoach with laboratory equipment (Vehrs et al., 2007). The focus was not training effects and no control group was included. Participants followed a 14 week program 3-5 sessions per week of 20-40 minutes of aerobic exercise at 65$85 \%$ HR max. Maximal graded exercise treadmill test were done before, after 7 weeks and at the end of the program. Relative $\mathrm{VO}_{2} \mathrm{max}$ improved significantly from $44.4 \pm 5.0$ to $46.0 \pm 5.2$ (7 weeks) to $47.8 \pm 5.6 \mathrm{ml} / \mathrm{min} / \mathrm{kg}$ (I 4 weeks), an overall improvement of $7.7 \%$. Absolute $\mathrm{VO}_{2} \mathrm{max}$ and sex differences were not reported. 
Tabel I. Results of studies without a training program (studies are listed by first author only although all papers have multiple authors)

\begin{tabular}{|c|c|c|c|c|c|c|c|}
\hline & $\begin{array}{l}\text { Training } \\
\text { status }\end{array}$ & $n$ & $\begin{array}{l}\text { Age } \\
\text { (yrs) }\end{array}$ & & & & \\
\hline \multirow{6}{*}{ Gursel 2004} & \multirow{6}{*}{$U$} & \multirow{6}{*}{90} & & Boys & Girls & Boys & Girls \\
\hline & & & $5-6$ & \multirow{5}{*}{\multicolumn{2}{|c|}{ * }} & 35.2 & 36.7 \\
\hline & & & $7-8$ & & & 38.1 & 37.4 \\
\hline & & & $9-10$ & & & 43.8 & 39.0 \\
\hline & & & $11-12$ & & & 46.3 & 41.4 \\
\hline & & & 13 & & & 48.0 & 40.5 \\
\hline \multirow{2}{*}{$\begin{array}{l}\text { Dencker } \\
2006 \\
\text { Dencker } \\
2007\end{array}$} & $U$ & 228 & 10 & \multicolumn{2}{|c|}{ * } & 42.0 & 36.0 \\
\hline & U & 248 & 10 & 1.42 & 1.21 & 41.4 & 35.8 \\
\hline Vinet 2003 & $U$ & 35 & 11 & 1.80 & 1.42 & 47.9 & 41.7 \\
\hline $\begin{array}{l}\text { Rowland } \\
2000\end{array}$ & $U$ & 25 & 12 & 1.98 & 1.84 & 47.2 & 40.4 \\
\hline \multirow{4}{*}{ Pate 2007} & $U$ & 3287 & $12-13$ & \multicolumn{2}{|c|}{ * } & 44.6 & 39.7 \\
\hline & & & $14-15$ & & & 47.1 & 38.3 \\
\hline & & & $16-17$ & & & 46.9 & 38.9 \\
\hline & & & $18-19$ & & & 47.6 & 37.5 \\
\hline \multirow{10}{*}{$\begin{array}{l}2006 \\
\text { Eisenmann } \\
2001\end{array}$} & $U$ & 1783 & 15 & \multicolumn{2}{|c|}{ * } & 46.6 & 38.8 \\
\hline & T & 124 & $9-10$ & 1.94 & 1.81 & 62.7 & 56.3 \\
\hline & & & 11 & 2.11 & 1.95 & 63.6 & 57.9 \\
\hline & & & 12 & 2.47 & 2.28 & 63.3 & 57.1 \\
\hline & & & 13 & 2.63 & 2.44 & 60.8 & 54.8 \\
\hline & & & 14 & 3.07 & 2.69 & 63.5 & 56.9 \\
\hline & & & 15 & 3.64 & 2.84 & 62.7 & 56.2 \\
\hline & & & 16 & 3.88 & 2.85 & 64.8 & 54.3 \\
\hline & & & 17 & 4.25 & 2.89 & 67.5 & 51.8 \\
\hline & & & 18 & 4.39 & - & 67.3 & - \\
\hline Noury 2004 & T & 24 & $9-11$ & 1.79 & 1.31 & 51.4 & 40.2 \\
\hline Tolfrey 2006 & T & 15 & 12 & 2.23 & - & \multicolumn{2}{|c|}{ * } \\
\hline $\begin{array}{l}\text { Cleuziou } \\
2002\end{array}$ & $T \& U$ & 20 & 13 & \multicolumn{2}{|c|}{ * } & \multicolumn{2}{|c|}{$\begin{array}{l}\text { U: } 38.7 \\
\mathrm{~T}: 52.4\end{array}$} \\
\hline Cubero 2000 & $\mathrm{~T}$ & 64 & $\begin{array}{l}15 \\
16 \\
17\end{array}$ & \multicolumn{2}{|c|}{ * } & $\begin{array}{l}53.0 \text { can. } \\
57.0 \text { cycl. } \\
48.0 \text { soc. }\end{array}$ & - \\
\hline $\begin{array}{l}\text { Thevenet } \\
2007\end{array}$ & $\mathrm{~T}$ & 8 & 16 & \multicolumn{2}{|c|}{ * } & 56.9 & - \\
\hline
\end{tabular}

T: trained subjects, U: untrained subjects, *: no results, can: canoeist, cycl: cycling, soc: soccer.

Samples of 75 male and 49 female elite distance runners 9-19 years were followed in a mixed-longitudinal design (Eisenmann et al., 200I). The age range thus spans the three sport development stages used in this review. The subjects ran about $35 \mathrm{~km}$ a week or more and some were followed up to 5 years. $\mathrm{VO}_{2}$ max was measured annually with an incremental treadmill test. The mixed-longitudinal data were pooled yielding observations for 139 males and 105 females. Over the duration of the study, absolute $\mathrm{VO}_{2}$ max of the runners 
increased significantly with age from $1.93 \pm 0.22 \mathrm{l} / \mathrm{min}$ at 9 years to $4.39 \pm 0.66$ $1 /$ min at 18 years in boys and from $1.81 \pm 0.18$ to $2.89 \pm 0.391 / \mathrm{min}$ in girls over the same ages. Relative $\mathrm{VO}_{2} \max$ remained relatively stable $(\sim 62.5 \mathrm{ml} / \mathrm{kg} / \mathrm{min})$ between 9 and 15 years in male runners, but increased $>67.0 \mathrm{ml} / \mathrm{kg} / \mathrm{min}$ between 16 and 19 years (investment years). Nevertheless, the improvement was not significant. Relative $\mathrm{VO}_{2}$ max was also stable in female runners $(\sim 56.0$ $\mathrm{ml} / \mathrm{kg} / \mathrm{min}$ ) across the sampling and specializing years but declined to $\sim 52.0$ $\mathrm{ml} / \mathrm{kg} / \mathrm{min}$ in the investment years; the change, however, was not significant.

Table 2. Characteristics of training studies (studies are listed by first author only although all papers have multiple authors)

\begin{tabular}{|c|c|c|c|c|c|}
\hline & $\begin{array}{c}\text { Training } \\
\text { status }\end{array}$ & $\begin{array}{c}\text { Mean age } \\
\text { (yrs), } n\end{array}$ & $\begin{array}{c}\text { Length } \\
\text { (wks), } \\
\# \text { sessions } \\
\text { per week }\end{array}$ & $\begin{array}{c}\text { Content, } \\
\text { Intensity, } \\
\text { Training time } \\
\text { (min) }\end{array}$ & $\begin{array}{l}\mathrm{VO}_{2} \text { max } \\
\text { Before } \\
\text { Training } \\
(\mathrm{I} / \mathrm{min})\end{array}$ \\
\hline \multicolumn{6}{|l|}{ Sampling years } \\
\hline Eliakim 2001 & $U$ & $\begin{array}{l}9.1 \\
40\end{array}$ & $\begin{array}{c}5 \\
10\end{array}$ & $\begin{array}{c}\text { Run + Ball, } \\
*, 90\end{array}$ & $\begin{array}{l}\text { EG G: * } \\
\text { CG G: }\end{array}$ \\
\hline McManus 1997 & $U$ & $\begin{array}{l}9.5 \\
30\end{array}$ & $\begin{array}{l}8 \\
3\end{array}$ & $\begin{array}{c}\text { Int/Con, } \\
\text { Max/165bpm, } \\
20\end{array}$ & $\begin{array}{l}\text { ITG G: } 1.54 \\
\text { CTG G: } 1.30 \\
\text { CG G: } 1.49\end{array}$ \\
\hline Baquet 2002 & $U$ & $\begin{array}{l}9.7 \\
53\end{array}$ & $\begin{array}{l}7 \\
2\end{array}$ & $\begin{array}{l}\text { Int, } \\
*, 30\end{array}$ & $\begin{array}{ll}\text { EG B\&G: } & 1.54 \\
\text { CG B\&G: } & 1.62\end{array}$ \\
\hline Nourry 2005 & $U$ & $\begin{array}{l}10.0 \\
18\end{array}$ & $\begin{array}{l}8 \\
2\end{array}$ & $\begin{array}{l}\text { Int, } \\
*, 30\end{array}$ & $\begin{array}{l}\text { EG B\&G: * } \\
\text { CG B\&G: * }\end{array}$ \\
\hline Williams 2000 & $U$ & $\begin{array}{c}10.1 \\
39\end{array}$ & $\begin{array}{l}8 \\
3\end{array}$ & $\begin{array}{c}\text { Int/Con, } \\
\text { Max/165bpm, } \\
20\end{array}$ & $\begin{array}{l}\text { ITG B: } 1.84 \\
\text { CTG B: } 1.80 \\
\text { CG B: } 1.92\end{array}$ \\
\hline Mandigout 2002 & $\cup$ & $\begin{array}{c}10.5 \\
19\end{array}$ & $\begin{array}{c}13 \\
3\end{array}$ & $\begin{array}{l}\text { Int, Con, Mxd, } \\
90 \%, 80 \%, 60\end{array}$ & $\begin{array}{l}\text { EG B\&G: * } \\
\text { CG B\&G: * }\end{array}$ \\
\hline McManus 2005 & $U$ & $\begin{array}{c}10.5 \\
35\end{array}$ & $\begin{array}{l}8 \\
3\end{array}$ & $\begin{array}{c}\text { Int/Con, } \\
\text { Max/165bpm, } \\
20\end{array}$ & $\begin{array}{l}\text { ITG B: } 1.76 \\
\text { CTG B: } 1.65 \\
\text { CG B: } 1.59\end{array}$ \\
\hline Tolfrey 1998 & $U$ & $\begin{array}{c}10.5 \\
45\end{array}$ & $\begin{array}{c}12 \\
3\end{array}$ & $\begin{array}{c}\text { Con, } \\
80 \%, \\
30\end{array}$ & $\begin{array}{l}\text { EG G: } 1.36 \\
\text { EG B: } 1.66 \\
\text { CG G: } 1.52 \\
\text { CG B: } 1.62\end{array}$ \\
\hline
\end{tabular}




\begin{tabular}{|c|c|c|c|c|c|}
\hline & $\begin{array}{c}\mathrm{VO}_{2} \text { max } \\
\text { after training } \\
(1 / \text { min })\end{array}$ & $\begin{array}{l}\text { Increase } \\
\text { absolute } \\
\mathrm{VO}_{2} \text { max }\end{array}$ & $\begin{array}{c}\mathrm{VO}_{2} \max \\
\text { before } \\
\text { training } \\
(\mathrm{ml} / \mathrm{kg} / \mathrm{min}) \\
\end{array}$ & $\begin{array}{c}\mathrm{VO}_{2} \max \\
\text { after } \\
\text { training } \\
(\mathrm{ml} / \mathrm{kg} / \mathrm{min}) \\
\end{array}$ & $\begin{array}{c}\text { Increase } \\
\text { relative } \\
\mathrm{VO}_{2} \text { max }\end{array}$ \\
\hline $\begin{array}{l}\text { Sampling years } \\
\text { Eliakim 200। }\end{array}$ & $\begin{array}{l}1.45 \\
*\end{array}$ & * & * & $\begin{array}{c}45.0 \\
*\end{array}$ & $9,5 \%$ \\
\hline McManus 1997 & $\begin{array}{l}1.67 \\
1.43 \\
1.46\end{array}$ & $\begin{array}{c}8.4 \% \\
10.0 \% \\
-\end{array}$ & * & * & * \\
\hline Baquet 2002 & $\begin{array}{l}1.68 \\
1.62\end{array}$ & $\begin{array}{c}9.1 \% \\
-\end{array}$ & $\begin{array}{l}43.9 \\
46.2\end{array}$ & $\begin{array}{l}47.5 \\
45.3\end{array}$ & $\begin{array}{c}8.2 \% \\
-\end{array}$ \\
\hline Nourry 2005 & * & * & $\begin{array}{l}37.4 \\
36.8\end{array}$ & $\begin{array}{l}43.2 \\
36.6\end{array}$ & $15.5 \%$ \\
\hline Williams 2000 & $\begin{array}{l}1.91 \\
1.93 \\
1.97\end{array}$ & $\begin{array}{l}3.8 \% \\
9.3 \% \\
2.6 \%\end{array}$ & $\begin{array}{l}54.8 \\
54.7 \\
56.4\end{array}$ & $\begin{array}{l}53.9 \\
57.5 \\
56.7\end{array}$ & $\begin{array}{c}- \\
5.1 \% \\
-\end{array}$ \\
\hline Mandigout 2002 & * & * & $\begin{array}{l}41.3 \\
45.9\end{array}$ & $\begin{array}{l}47.9 \\
45.1\end{array}$ & $\begin{array}{c}16.0 \% \\
-\end{array}$ \\
\hline McManus 2005 & $\begin{array}{l}1.96 \\
1.72 \\
1.57\end{array}$ & $\begin{array}{c}11.4 \% \\
4.2 \% \\
-\end{array}$ & $\begin{array}{l}47,0 \\
45,5 \\
44.7\end{array}$ & $\begin{array}{l}50,7 \\
50,7 \\
45.4\end{array}$ & $\begin{array}{c}7,9 \% \\
11,4 \% \\
1.6 \%\end{array}$ \\
\hline Tolfrey 1998 & $\begin{array}{l}1.54 \\
1.66 \\
1.52 \\
1.65\end{array}$ & $\begin{array}{c}13.2 \% \\
3.8 \% \\
- \\
1.9 \% \\
\end{array}$ & $\begin{array}{l}39.9 \\
46.6 \\
44.7 \\
50.7\end{array}$ & $\begin{array}{l}42.4 \\
47.2 \\
43.0 \\
50.3\end{array}$ & $\begin{array}{c}7.9 \% \\
1.3 \% \\
- \\
- \\
\end{array}$ \\
\hline
\end{tabular}

(continues)

\begin{tabular}{|c|c|c|c|c|c|}
\hline & $\begin{array}{c}\text { Training } \\
\text { status }\end{array}$ & $\begin{array}{c}\text { Mean age } \\
(\mathrm{yrs}), \mathrm{n}\end{array}$ & $\begin{array}{l}\text { Length (wks), } \\
\text { \# sessions } \\
\text { per week }\end{array}$ & $\begin{array}{c}\text { Content, } \\
\text { Intensity, } \\
\text { training time } \\
\text { (min) }\end{array}$ & $\begin{array}{c}\mathrm{VO}_{2} \max \text { Before } \\
\text { Training } \\
\text { (I/min) }\end{array}$ \\
\hline Mandigout 2001 & $U$ & $\begin{array}{c}10.5 \\
85\end{array}$ & $\begin{array}{c}13 \\
3\end{array}$ & $\begin{array}{c}\text { Int, Con, Mxd, } \\
90 \%, 80 \% \\
60\end{array}$ & $\begin{array}{l}\text { EG G } 1.30 \\
\text { EG B } 1.70 \\
\text { CG G: } 1.40 \\
\text { CG B: } 1.60\end{array}$ \\
\hline Obert 2003 & $U$ & $\begin{array}{l}10.6 \\
35\end{array}$ & $\begin{array}{c}13 \\
3\end{array}$ & $\begin{array}{l}\text { Int, Con, } \\
90 \%, 80 \% \text {, } \\
60\end{array}$ & * \\
\hline Mandigout 2002 & $U$ & $\begin{array}{c}10-11 \\
84\end{array}$ & $\begin{array}{c}13 \\
3 \& 2\end{array}$ & $\begin{array}{c}\text { Int, Con, } \\
(M \times d) \\
90 \%, 80 \% \\
60\end{array}$ & $\begin{array}{l}\text { EGI G: } 1.37 \\
\text { EG2 G: } 1.44 \\
\text { EG1 B: } 1.71 \\
\text { EG2 B: } 1.66 \\
\text { CG G: } 1.45 \\
\text { CG B: } 1.69\end{array}$ \\
\hline Rowland 1996 & $U$ & $\begin{array}{l}11.8 \\
29\end{array}$ & $\begin{array}{c}13 \\
3\end{array}$ & $\begin{array}{c}\text { Mxd, } \\
175 \mathrm{bpm}, 30\end{array}$ & $\begin{array}{l}\text { G: } 1.81 \\
\text { B: } 2.08 \\
\text { CG: - }\end{array}$ \\
\hline Rowland I995 & $U$ & $\begin{array}{c}11-13 \\
37\end{array}$ & $\begin{array}{c}12 \\
3\end{array}$ & $\begin{array}{c}\text { Mxd, } \\
\text { I } 70 \text { bpm, } 30\end{array}$ & $\begin{array}{c}\text { EG B\&G: } 2.02 \\
\text { CG: - }\end{array}$ \\
\hline Obert 1996 & $\mathrm{~T}$ & $\begin{array}{l}9.3 \\
14\end{array}$ & $\begin{array}{l}52 \\
10\end{array}$ & $\begin{array}{c}\text { Mxd swim tr, } \\
\quad *, 120\end{array}$ & $\begin{array}{l}\text { EG G: } 0.79 \\
\text { CG G: } 0.69\end{array}$ \\
\hline Vamvakoudis 2007 & $\mathrm{~T}$ & $\begin{array}{l}11.5 \\
38\end{array}$ & $\begin{array}{c}78 \\
6\end{array}$ & $\begin{array}{c}\text { Mxd basket } t r, \\
*, 90\end{array}$ & $\begin{array}{l}\text { EG B: } 2.31 \\
\text { CG B: } 2.11\end{array}$ \\
\hline
\end{tabular}

(continues) 


\begin{tabular}{|c|c|c|c|c|c|}
\hline & $\begin{array}{l}\mathrm{VO}_{2} \text { max after } \\
\text { training }(1 / \mathrm{min})\end{array}$ & $\begin{array}{l}\mathrm{VO}_{2} \text { max } \\
\text { absolute } \\
\text { VO2-max }\end{array}$ & $\begin{array}{c}\mathrm{VO}_{2} \mathrm{max} \\
\text { before } \\
\text { Training } \\
(\mathrm{ml} / \mathrm{min} / \mathrm{kg}) \\
\end{array}$ & $\begin{array}{c}\mathrm{VO}_{2} \mathrm{max} \\
\text { after } \\
\text { training } \\
(\mathrm{ml} / \mathrm{min} / \mathrm{kg})\end{array}$ & $\begin{array}{l}\text { Increase } \\
\text { Relative } \\
\mathrm{VO}_{2} \text { max }\end{array}$ \\
\hline \multirow[t]{4}{*}{ Mandigout 200I } & 1.57 & $20.7 \%$ & 38.6 & 41.9 & $8.5 \%$ \\
\hline & 1.84 & $8.2 \%$ & 47.2 & 49.2 & $4.2 \%$ \\
\hline & 1.50 & $7.1 \%$ & 39.6 & 39.5 & - \\
\hline & 1.70 & $6.3 \%$ & 46.1 & 45.5 & - \\
\hline \multirow[t]{4}{*}{ Obert 2003} & * & * & EG G: 40.9 & 44.2 & $8.1 \%$ \\
\hline & & & EG B: 44.1 & 50.9 & $15.4 \%$ \\
\hline & & & CG G: 42.4 & 42.6 & - \\
\hline & & & CG B: 51.5 & 50.3 & - \\
\hline \multirow{6}{*}{ Mandigout 2002} & 1.57 & $14.6 \%$ & 38.2 & 41.5 & $8.6 \%$ \\
\hline & 1.50 & $4.2 \%$ & 40.1 & 40.6 & $1.2 \%$ \\
\hline & 1.82 & $6.4 \%$ & 46.9 & 49.3 & $5.1 \%$ \\
\hline & 1.70 & $2.4 \%$ & 45.5 & 45.2 & - \\
\hline & 1.55 & $6.9 \%$ & 41.1 & 40.1 & - \\
\hline & 1.72 & $1.8 \%$ & 46.6 & 45.6 & - \\
\hline \multirow[t]{2}{*}{ Rowland 1996} & 1.97 & $8.8 \%$ & 43.9 & 46.1 & $5.0 \%$ \\
\hline & 2.29 & $6.5 \%$ & 45.4 & 48.2 & $6.2 \%$ \\
\hline Rowland 1995 & 2.24 & 10.9 & 44.7 & 47.6 & $6.5 \%$ \\
\hline \multirow[t]{2}{*}{ Obert 1996} & 1.10 & $39.2 \%$ & 26.2 & 33.8 & $29 \%$ \\
\hline & 0.79 & $14.5 \%$ & 24.7 & 24.9 & - \\
\hline \multirow{2}{*}{ Vamvakoudis 2007} & 3.11 & $34.6 \%$ & 51.4 & 55.8 & $8.6 \%$ \\
\hline & 2.62 & $24.2 \%$ & 42.2 & 45.6 & $8.1 \%$ \\
\hline
\end{tabular}

(continues)

\begin{tabular}{|c|c|c|c|c|c|}
\hline & $\begin{array}{c}\text { Training } \\
\text { status }\end{array}$ & $\begin{array}{c}\text { Mean age } \\
(y r s), n\end{array}$ & $\begin{array}{c}\text { Length (wks), } \\
\# \text { sessions per } \\
\text { week }\end{array}$ & $\begin{array}{c}\text { Content, } \\
\text { Intensity, } \\
\text { training time } \\
\text { (min) }\end{array}$ & $\begin{array}{l}\mathrm{VO}_{2} \mathrm{max} \\
\text { Before } \\
\text { Training } \\
\text { (l/min) }\end{array}$ \\
\hline \multicolumn{6}{|l|}{ Specializing years } \\
\hline Danis 2002 & $U$ & $\begin{array}{c}11-14 \\
18\end{array}$ & $\begin{array}{c}26 \\
3\end{array}$ & $\begin{array}{l}\text { Run, } \\
*, 60\end{array}$ & $\begin{array}{l}\text { EG B: } 2.08 \\
\text { CG B: } 2.10\end{array}$ \\
\hline Stoedefalke 2000 & $U$ & $\begin{array}{c}13-14 \\
38\end{array}$ & $\begin{array}{c}20 \\
3\end{array}$ & $\begin{array}{c}\text { Mxd, } \\
80 \%, 20\end{array}$ & $\begin{array}{l}\text { EG G: } 2.25 \\
\text { CG G: } 2.39\end{array}$ \\
\hline Bogdanis 2007 & $\mathrm{~T}$ & $\begin{array}{c}14.7 \\
27\end{array}$ & $\begin{array}{l}4 \\
5\end{array}$ & $\begin{array}{c}\text { Mxd basket, } \\
*, \\
110\end{array}$ & * \\
\hline \multicolumn{6}{|l|}{ Investment years } \\
\hline Eliakim 1996 & $U$ & $\begin{array}{c}15-17 \\
44\end{array}$ & $\begin{array}{l}5 \\
5\end{array}$ & $\begin{array}{l}\text { Mxd, } \\
* .120\end{array}$ & $\begin{array}{l}\text { EG G: } 1.48 \\
\text { CG G: } 1.57\end{array}$ \\
\hline Vehrs 2007 & $U$ & $\begin{array}{l}19.5 \\
16\end{array}$ & $\begin{array}{r}14 \\
3-5\end{array}$ & $\begin{array}{l}\text { Mxd, } \\
75 \% \\
30\end{array}$ & * \\
\hline Plank 2005 & $\mathrm{~T}$ & $\begin{array}{l}15.9 \\
9\end{array}$ & $\begin{array}{c}13 \\
5\end{array}$ & $\begin{array}{l}\text { Run, } \\
m \times d, 60\end{array}$ & $\begin{array}{c}\text { EG B: } 3.73 \\
\text { CG: - }\end{array}$ \\
\hline
\end{tabular}

(continues) 


\begin{tabular}{|c|c|c|c|c|c|}
\hline & $\begin{array}{l}\mathrm{VO}_{2} \text { max after } \\
\text { training }(1 / \mathrm{min})\end{array}$ & $\begin{array}{l}\text { Increase } \\
\text { absolute } \\
\text { VO2-max }\end{array}$ & $\begin{array}{c}\mathrm{VO}_{2} \max \\
\text { before } \\
\text { Training } \\
(\mathrm{ml} / \mathrm{min} / \mathrm{kg}) \\
\end{array}$ & $\begin{array}{c}\mathrm{VO}_{2} \mathrm{max} \\
\text { after } \\
\text { training } \\
(\mathrm{ml} / \mathrm{min} / \mathrm{kg}) \\
\end{array}$ & $\begin{array}{l}\text { Increase } \\
\text { Relative } \\
\mathrm{VO}_{2} \text { max }\end{array}$ \\
\hline \multicolumn{6}{|l|}{ Specializing years } \\
\hline \multirow[t]{2}{*}{ Danis 2002} & 2.37 & $13.9 \%$ & 52.1 & 57.5 & $10.4 \%$ \\
\hline & 2.32 & $10.5 \%$ & 54.0 & 55.4 & $2.6 \%$ \\
\hline \multirow[t]{2}{*}{ Stoedefalke 2000} & 2.32 & $3.1 \%$ & * & * & * \\
\hline & 2.45 & $2.5 \%$ & & & \\
\hline \multirow{3}{*}{ Bogdanis 2007} & * & * & EGI B: 52.3 & 54.7 & $4.6 \%$ \\
\hline & & & EG2 B: 52.5 & 54.9 & $4.6 \%$ \\
\hline & & & CG B: 49.8 & 49.4 & - \\
\hline \multirow{2}{*}{$\begin{array}{l}\text { Investment years } \\
\text { Eliakim } 1996\end{array}$} & & & & & \\
\hline & $\begin{array}{c}1.63 \\
*\end{array}$ & $12.1 \%$ & * & * & * \\
\hline Vehrs 2007 & * & * & $\begin{array}{c}\text { EG B\&G: } 44.4 \\
\text { CG: - }\end{array}$ & 47.8 & $7.7 \%$ \\
\hline Plank 2005 & 3.98 & $6.7 \%$ & 61.6 & 65.3 & $6.0 \%$ \\
\hline
\end{tabular}

*No values reported, G: values for girls, B: values for boys, B+G: values for boys and girls separated, B\&G: values of boys and girls not separated, ITG: Interval Training Group, CTG: Continuous Training Group, EG: Experimental Group, CG: Control Group, T: trained subjects, U: untrained subjects, Mxd: mixed training types, Run: running training, Int: interval training, Con: continuous training

\section{DISCUSSION}

Changes in absolute $\mathrm{VO}_{2}$ max associated with training vary from $2.4 \%$ to $39.2 \%$ with a slightly higher mean increase girls $( \pm 12,5 \%)$ than in boys $( \pm 10 \%)$. All studies except one (Williams et al., 2000) also show at least small increments in relative $\mathrm{VO}_{2} \max$ with training and the mean increase was higher in girls $( \pm 10 \%)$ than in boys $( \pm 6.5 \%)$.

One of the goals of this study was to evaluate variation in trainability during three three sport development stages proposed by Côté and Hay (2002). Accordingly, the focus shifts from sampling ( 6-12 years) through specializing ( $\sim 3-15$ years) into investment years $(\sim 16+$ years $)$ on a continuum from deliberate play to deliberate practice. The goal of deliberate practice is to improve an aspect of performance. In the context of the present review, the performance focus is $\mathrm{VO}_{2}$ max. Most studies in the last 15 years concerned the trainability of $\mathrm{VO}_{2} \max$ in the age range spanning the sampling years, while few studies considered the specializing (Bogdanis et al., 2007; Danis et al., 2002; Stoedefalke et al., 2000) and investment years (Eliakim et al., 1996; Plank et al., 2005; Vehrs et al., 2007) years. One study was spanned all three sport development stages (Eisenmann et al., 200 I).

Figure la shows absolute $\mathrm{VO}_{2}$ max reported in all studies reviewed. Values from studies without a training program and at the beginning of a training program from the studies with an intervention are used to form a 
baseline that probably reflect normal growth of $\mathrm{VO}_{2} \max$. Absolute $\mathrm{VO}_{2} \max$ increases almost linearly to about 15 years after which girls appear to reach a plateau and boys continue to improve. This is consistent with earlier discussions (Krahenbuhl et al., 1985; Bar-Or, 1986; Rowland, 1996; Armstrong et al., 2000). Trained children and adolescents show higher values than untrained peers of both sexes, but there appears to be no difference in the manner of increase in $\mathrm{VO}_{2} \mathrm{max}$ across age. This implies that starting training at younger age (sampling years) does not temper an increase in $\mathrm{VO}_{2}$ max at older ages (specializing and investment years). It is not possible, however, to state that starting training during the sampling years will give an advantage for the other stages and adulthood. The 10-year rule (Ericsson et al., 1993), however, proposes that deliberate practice is necessary to reach elite level so that starting at a younger age should have an advantage compared to starting at later age.

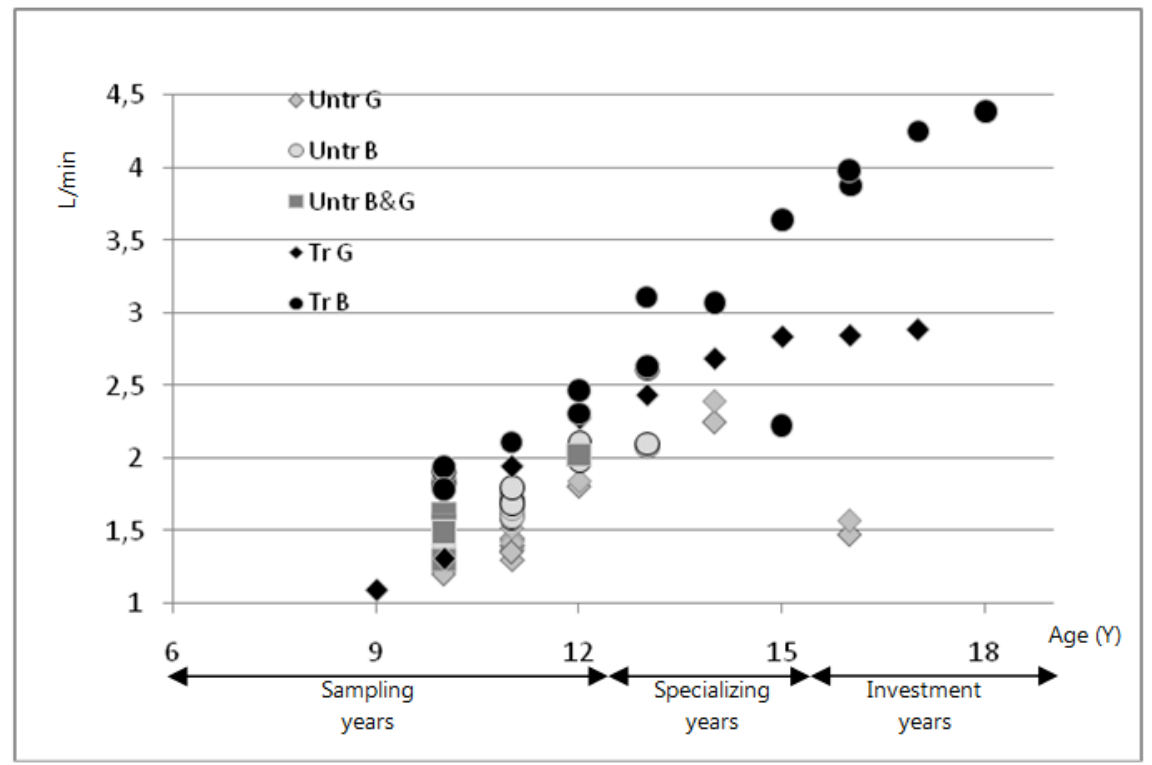

Figure Ia. Absolute $\mathrm{VO}_{2} \mathrm{max}$ in $\mathrm{I} / \mathrm{min}$ by age. Legend: [Untr] untrained; [ $\mathrm{Tr}$ ] trained; $[\mathrm{G}]$ girls; [B] boys, $[\mathrm{B} \& \mathrm{G}]$ boys\&girls 


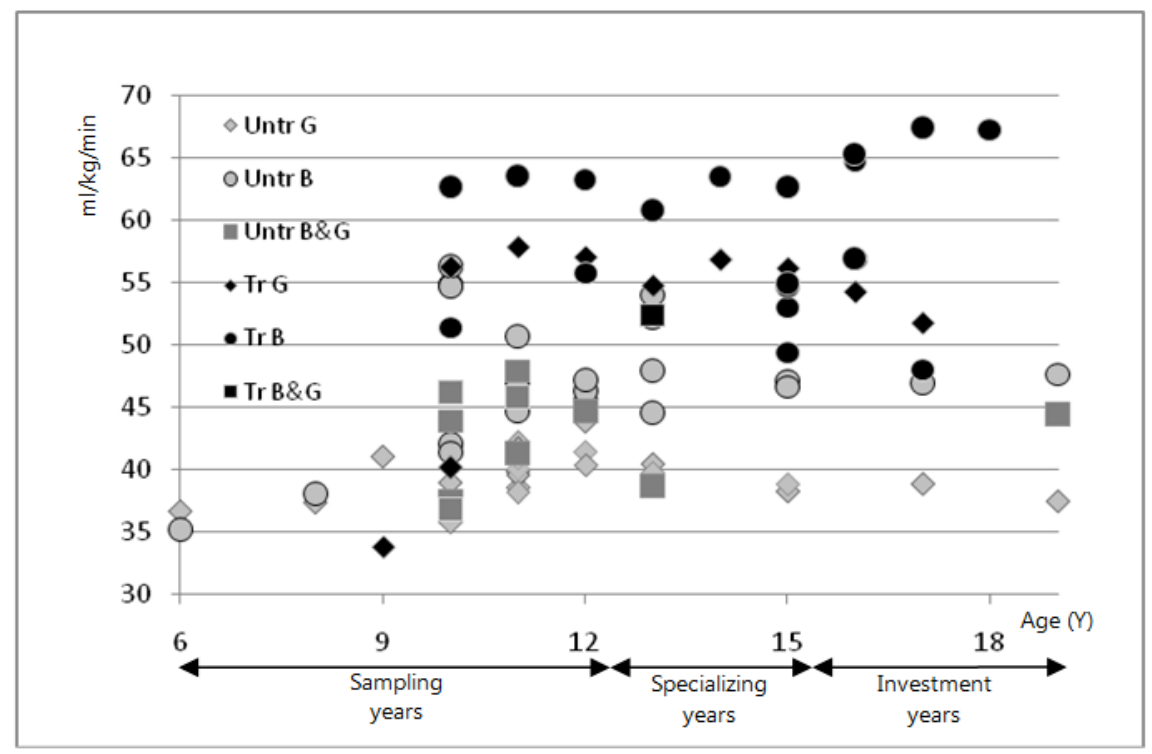

Figure Ib. Relative $\mathrm{VO}_{2} \mathrm{max}$ in $\mathrm{ml} / \mathrm{kg} / \mathrm{min}$ by age. Legend: [Untr] untrained; [ $\mathrm{Tr}$ ] trained; [G] girls; [B] boys, [B\&G] boys\&girls

Figure Ib shows corresponding values for relative $\mathrm{VO}_{2}$ max. In general, trained children and adolescents have higher values compared to untrained peers. Only two results for trained girls were lower than expected. One study using a swim ergometer to measure $\mathrm{VO}_{2} \max$ (Obert et al., 1996), while use of only upper body musculature gives lower results than use of lower body musculature (Al-Hazzaa et al., 1998). Relative $\mathrm{VO}_{2}$ max seems to improve during the sampling years but tends to remain stable during the subsequent stages in both sexes. This is not totally consistent with the literature (Krahenbuhl et al., 1985; Bar-Or, 1986; Rowland, 1996) which shows a decline in relative value in girls after about of 10 years of age. Although trained youth have higher values than the untrained, it appears to be difficult to improve relative $\mathrm{VO}_{2} \mathrm{max}$ in trained children and adolescents. Limited data for the investment years show a slight increase in males but a small decrease in females. Hence, generalizations are not warranted.

To show an influence of training on improvement in $\mathrm{VO}_{2} \mathrm{max}$ it is necessary to partition observations attributed to training from normal growth and maturation. Figures $2 \mathrm{a}$ and $2 \mathrm{~b}$ show differences between experimental and control groups for all studies. Experimental groups trained 2 to 10 times per week for durations of 20 to 120 minutes over periods of 4 to 78 weeks. Improvements are divided into four categories; no improvement (less than I\%), low improvement (I-5\%), moderate improvement (6-10\%), and high 
improvement (>10\%). For both absolute and relative $\mathrm{VO}_{2} \mathrm{max}$ 'no' improvement is observed largely within control groups. Only one experimental group shows 'no' improvement in relative $\mathrm{VO}_{2} \mathrm{max}$, while all experimental groups show at least low improvement in absolute $\mathrm{VO}_{2}$ max. The observation of 'no' improvement in relative $\mathrm{VO}_{2} \max$ is consistent with a stable pattern during childhood and adolescence. While absolute $\mathrm{VO}_{2} \max$ is more liable to growth and maturational effects, it is not surprising that some control groups show 'moderate' and even 'high' improvements. These results were found in studies of longer duration. Nevertheless, experimental groups showed higher improvements in absolute $\mathrm{VO}_{2} \max$ in these studies that exceed the effects of growth and maturation. Most experimental groups show moderate and high improvement for both absolute and relative $\mathrm{VO}_{2} \mathrm{max}$.

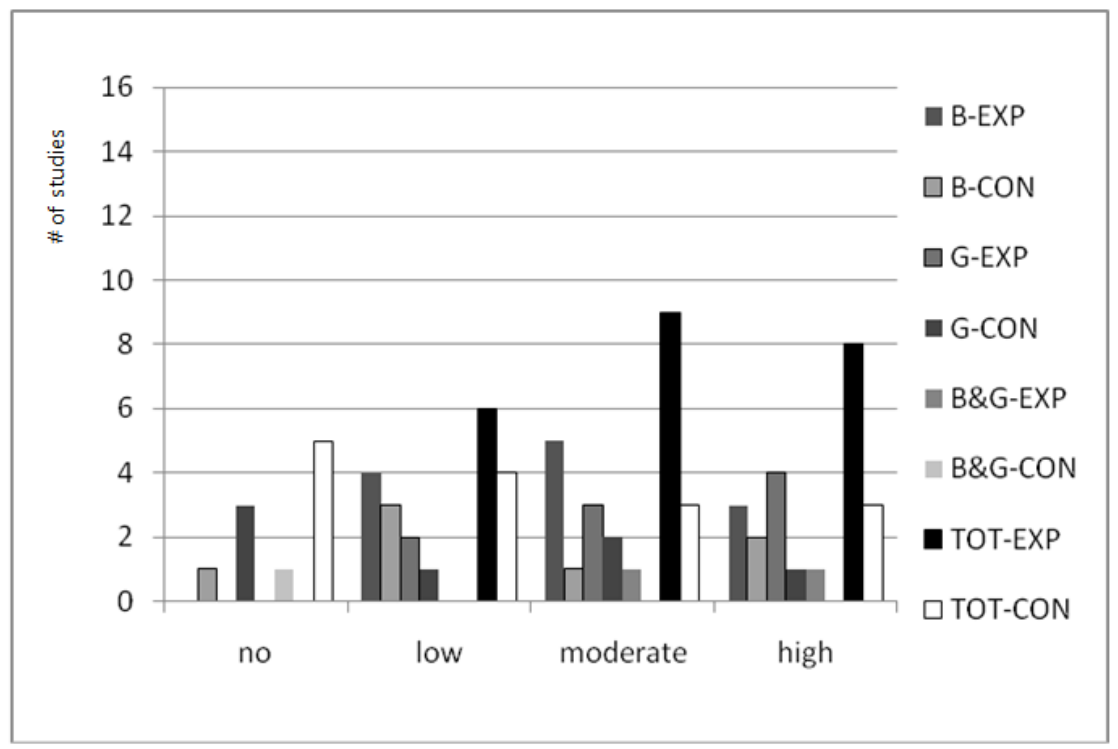

Figure 2a. Number of studies for each category of improvement of absolute $\mathrm{VO}_{2} \mathrm{max}$. Legend: [B] boys; [G] girls; [B\&G] boys\&girls; [Exp] experimental group; [Con] control group; [Tot] total 


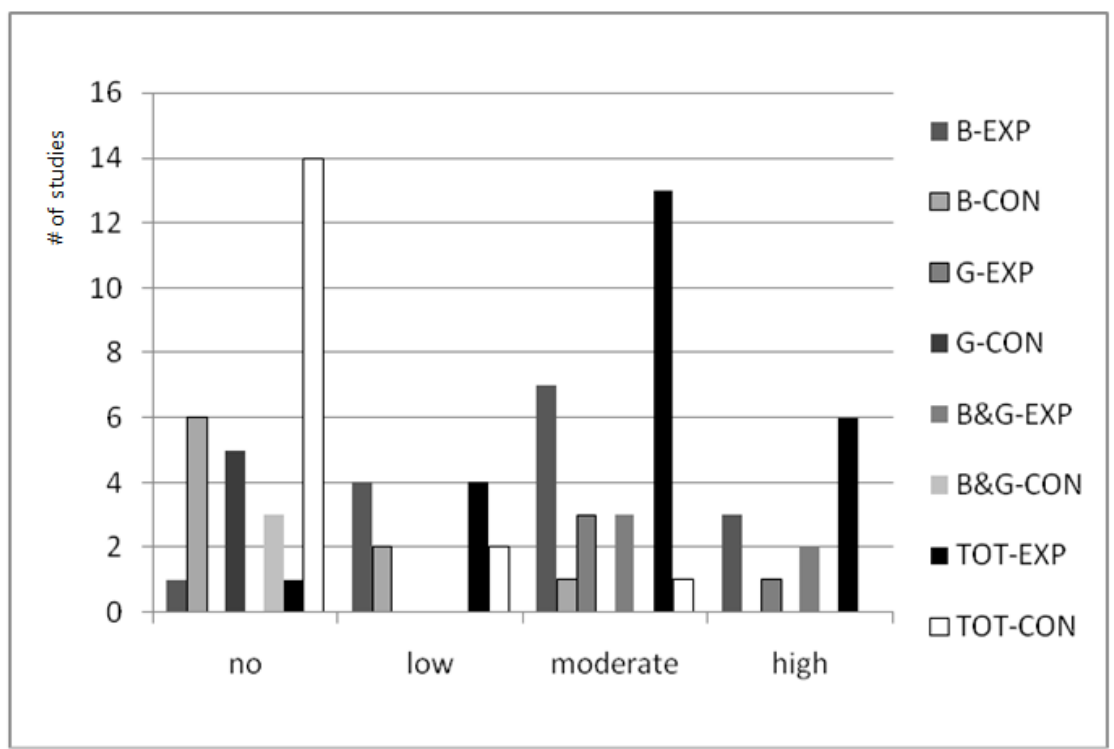

Figure 2b-number of studies for each category of improvement of relative $\mathrm{VO}_{2}$ max. Legend: [B] boys; [G] girls; [B\&G] boys\&girls; [Exp] experimental group; [Con] control group; [Tot] total.

Figures $3 \mathrm{a}$ and $3 \mathrm{~b}$ show relative improvement (\%) in $\mathrm{VO}_{2}$ max associated with training. During the sampling years improvements in absolute $\mathrm{VO}_{2} \mathrm{max}$ are in a similar range for both trained and untrained children (3\% to 20\%). Only two studies reported improvements $>30 \%$ in absolute $V_{2}$ max (Obert et al., 1996; Vamvakoudis et al., 2007). These studies spanned 52 and 78 weeks so that the larger improvements were due in part to growth and maturation since control groups showed high improvements, $14.5 \%$ and $24.2 \%$, over the same periods. Improvements for trained youth tend to be lower during the specializing and investment years than during the sampling years though data are too limited for generalization. 


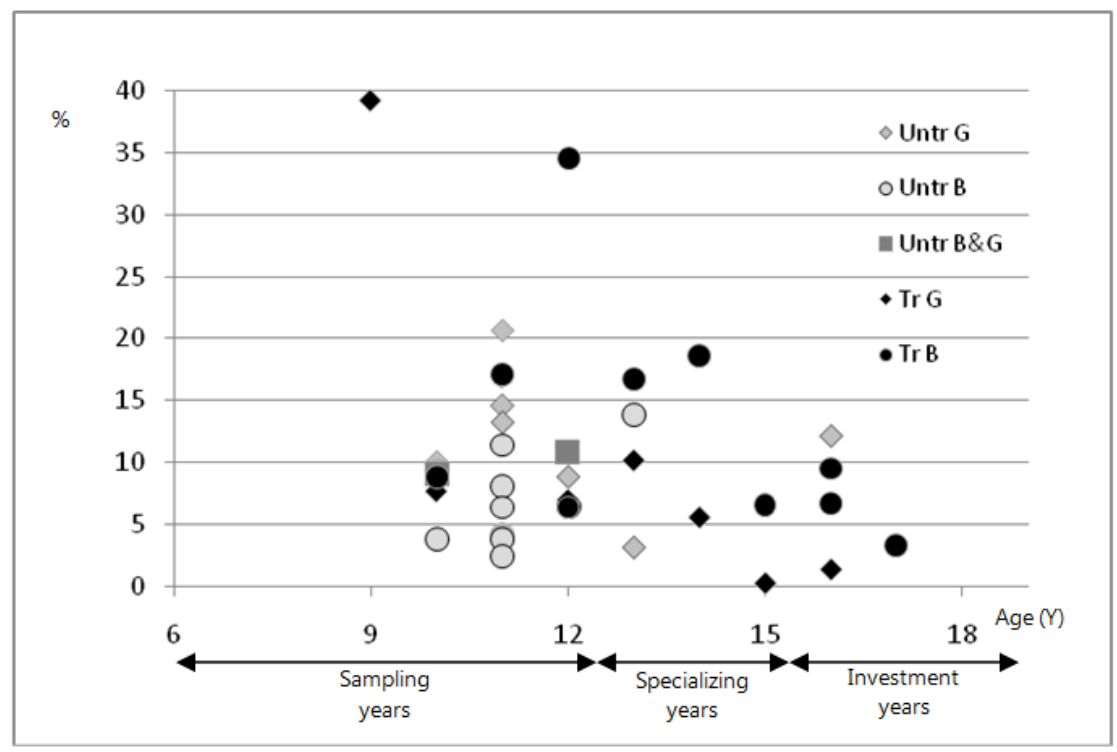

Figure $3 \mathrm{a}$. Percentage improvement of absolute $\mathrm{VO}_{2}$ max due to training. Legend: [Untr] untrained; [Tr] trained; [G] girls; [B] boys; [B\&G] boys\&grirls.

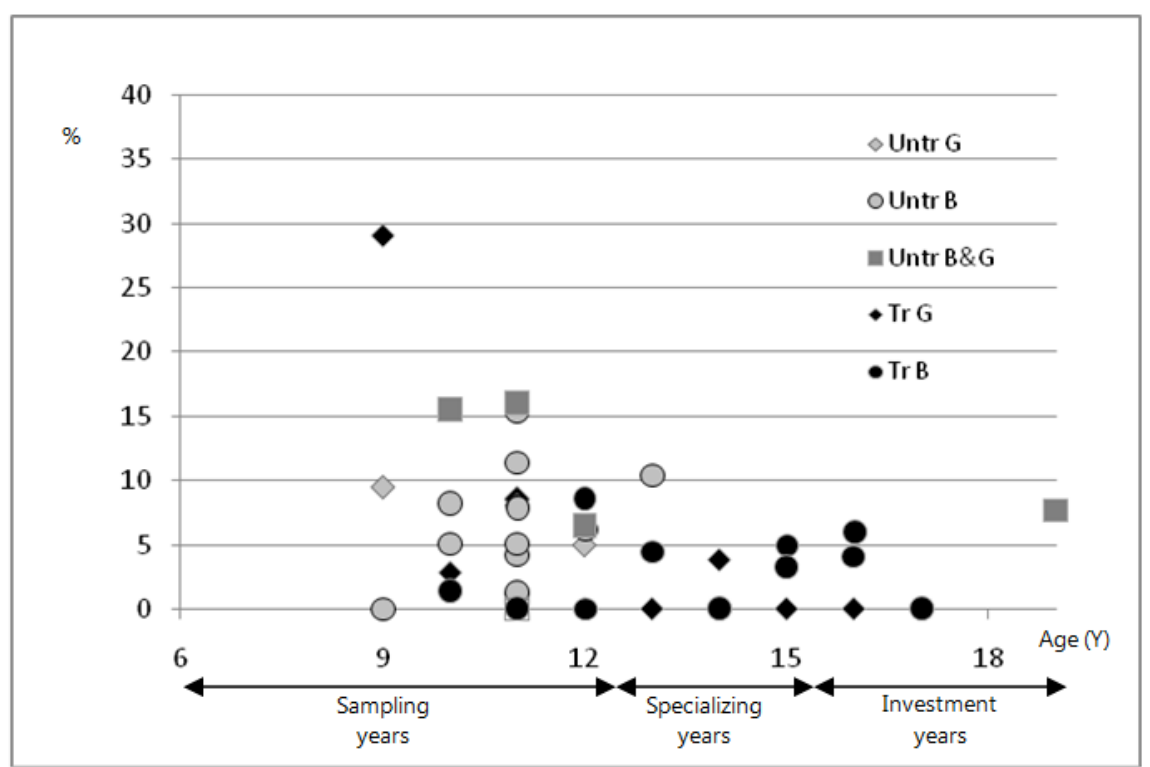

Figure 3b. Percentage improvement of relative $\mathrm{VO}_{2} \mathrm{max}$ due to training. Legend: [Untr] untrained; [Tr] trained; [G] girls; [B] boys; [B\&G] boys\&grirls. 
A training program of 7 weeks with 3 sessions perweek seems sufficient to improve $\mathrm{VO}_{2}$ max. Longer training periods do not show consistently better results, especially for relative $\mathrm{VO}_{2}$ max. Although highest improvements of absolute $\mathrm{VO}_{2}$ max were noted in studies with training periods $>26$ weeks, it is difficult to partition training from changes associated with normal growth and maturation.

More than 3 training sessions a week does not show consistently better results, whereas two sessions per week seem appear to be insufficient to improve $\mathrm{VO}_{2 m a x}$. Although two studies (Baquet et al., 2002; Nourry et al., 2005) used two sessions per week, the sessions were added to the normal physical education classes. In most studies training replaced at least one physical education class. With only two sessions a week, time between sessions seems to be too long for improvement to occur. This is consistent with training principles that a new impulse should occur close enought in time to bring about an effect.

The studies considered differed in training intensity and duration so that it is almost impossible to conclude which intensity is most effective. Studies generally used different training protocols during a week. One session usually consisted of interval (maximal sprints) training and another of continuous (80\% of HR max or 160-180 bpm) training, while a third session included mixed activities such as ball sports and dancing. The few studies that compared interval training with continuous training showed no consistent results. Accordingly, it is not possible to conclude if one type of training is more effective than another to improve $\mathrm{VO}_{2} \mathrm{max}$ in children and adolescents, but heart rate should be at least 160 bpm. It is also difficult to draw a conclusion on an effective training duration. Training sessions in the studies varied between 20 minutes and 2 hours. Longer sessions did not show higher improvements than shorter sessions. Moreover, training sessions of 20 minutes appear effective in improving $\mathrm{VO}_{2}$ max.

Although some results show reasonable consistency, the relatively small number of studies in combination with variation in sampling, numbers of subjects, design and protocols limits generalization. It is likely that training studies would not attract overweight and obese youth. Another confounder is failure to control for pubertal status and timing of the adolescent growth spurt. Absolute $\mathrm{VO}_{2}$ max shows its own growth spurt that occurs, on average, coincident with the growth spurt in height in both sexes (Malina et al., 2004). More comprehensive research designs are needed to better understand the influence of systematic training on growth of $\mathrm{VO}_{2}$ max at different ages during childhood and adolescence. 


\section{REFERENCES}

Al-Hazzaa HM, Al-Refaee SA, Sulaiman MA (1998) Cardiorespiratory responses of trained boys to treadmill and arm ergometry: Effect of training specificity. Pediatric Exercise Science 10: 264-276.

Armstrong N \& Welsman JR (2000) Development of aerobic fitness during childhood and adolescence. Pediatric Exercise Science 12: 128-149.

Baquet G, Berthoin S, Dupont G, Blondel N, Fabre C, Van Praagh E (2002) Effects of high intensity intermittent training on peak VO2 in prepubertal children. International Journal of Sport Medicine 23: 439-444.

Baquet G, Van Praagh E, Berthoin S (2003) Endurance training and aerobic fitness in young people. Sports Medicine 15: I | 27- I | 43.

Bar-Or O (1986) Pathophysiological factors which limit the exercise capacity of the sick child. Medicine and Science in Sports and Exercise I8: 276-282.

Bogdanis GC, Ziagos V, Anastasiadis M, Maridaki M (2007) Effects of two different short-term training programs on the physical and technical abilities of adolescent basketball players. Journal of Science and Medicine in Sport 10: 79-88.

Bouchard C, Malina RM, Perusse L (1997) Genetics of Physical Fitness and Performance. Champaign, IL: Human Kinetics.

Cleuziou C, Lecoq AM, Candau R, Courteix D, Guenon P, Obert P (2002) Kinetics of oxygen uptake at the onset of moderate and heavy exercise in trained and untrained prepubertal children. Science and Sports 17: 291-296.

Cote J, Hay J (2002) Children's involvement in sport: A developmental perspective. In JM Silva, D Stevens (Eds), Psychological foundations of sport, $2^{\text {nd }}$ edition. Boston: Merill, pp 484-502.

Cubero Gl, Batalla A, Reguero JJR, Barriales R, Gonzales V, De la lglesia JL, Terrados N (2000) Left ventricular mass index and sports: the influence of different sports activities and arterial blood pressure. International Journal of Cardiology 75: 26I-265

Danis A, Kyriazis Y, Klissouras V (2003) The effect of training in male prepubertal and pubertal monozygotic twins. European Journal of Applied Physiology 89: 309-3 I 8.

Dencker M, Thorsson O, Karlsson MK, Lindén C, Svenson J, Wollmer P, Andersen LB (2006) Daily physical activity and its relation to aerobic fitness in children aged 8I I years. European Journal of Applied Physiology 96: 587-592.

Dencker M, Thorsson $\mathrm{O}$, Karlsson MK, Lindén C, Eiberg S, Wollmer P, Andersen LB (2007) Gender differences and determinants of aerobic fitness in children aged 8II years. European Journal of Applied Physiology 99: 19-26.

Eisenmann JC, Pivarnik JM, Malina RM (200I) Scaling peak Vo2 to body mass in young male and female distance runners. Journal of Applied Physiology 90: 2172-2180.

Eliakim A, Barstow TJ, Brasel JA, Ajie H, Lee PWN, Renslo R, Berman N, Cooper DM (1996) Effect of exercise training on energy expenditure, muscle volume, and maximal oxygen uptake in female adolescents. Journal of Pediatrics 129: 537-543.

Eliakim A, Scheett T, Brasel JA, Allmendinger N, Cooper DM (200I) Training, muscle volume, and energy expenditure in nonobese American girls. Journal of Applied Physiology 90: 35-44.

Ericsson KA (2003) Development of elite performance and deliberate practice. An update from the perspective of the expert performance approach. In JL Starkes, KA Ericsson (Eds), Expert Performance in Sports. Champaign, IL: Human Kinetics, pp 50-87. 
Ericsson KA, Krampe RT, Tesch-Römer C (1993) The role of deliberate practice in the acquisition of expert performance. Psychological Review, I00, 363-406.

Gilliam TB, Freedson PS (1980) Effects of a 12 week school physical fitness program on peak VO2-max, body composition, and blood lipids in 7 to 9 year old children. International Journal of Sports Medicine 1: 73-78.

Gursel Y, Sonel B, Gok H, Yalcin P (2004) The peak oxygen uptake of healthy Turkish children with reference to age and sex: a pilot study. Turkish Journal of Pediatrics, 46: 38-43.

Imperatore G, Cheng YLJ, Williams DE, Fulton J, Gregg EW (2006) Physical activity, cardiovascular fitness, and insulin sensitivity among US adolescents - The National Health and Nutrition Examination Survey, 1999-2002. Diabetes Care 29: 15671572 .

Krahenbuhl GS, Skinner JS, Kohrt WM (1985). Developmental aspects of maximal aerobic power in children. Exercise and Sport Science 13: 503-538.

Malina RM, Bouchard C, Bar-Or O (2004) Growth, Maturation, and Physical Activity, $2^{\text {nd }}$ edition. Champaign, IL: Human Kinetics.

Mandigout S, Lecoq AM, Courteix D, Guenon P, Obert P (200I) Effect of gender in response to an aerobic training programme in prepubertal children. Acta Paediatrica 90: 9- I5.

Mandigout S, Melin A, Lecoq AM, Courteix D, Obert P (2002) Effect of two aerobic training regimens on the cardiorespiratory response of prepubertal boys and girls. Acta Paediatrica 91: 403-408.

Mandigout S, Melin A, Fauchier L, N'Guyen LD, Courteix D, Obert P (2002) Physical training increases heart rate variability in healthy prepubertal children. European Journal of Clinical Investigation, 32: 479-487

McManus AM, Armstrong N, Williams CA (1997) Effect of training on the aerobic power and anaerobic performance of prepubertal girls. Acta Paediatrica 86: 456459.

McManus AM, Cheng CH, Leung MP, Yung TC, Macfarlane DJ (2005) Improving aerobic power in primary school boys: A comparison of continuous and interval training. International Journal of Sport Medicine 26: 78I-786.

Nottin S, Vinet A, Stecken F, N'Guyen LD, Ounissi F, Lecoq AM, Obert P (2002) Central and peripheral cardiovascular adaptations to exercise in endurance-trained children. Acta Physiologica Scandinavica 175: 85-92.

Nourry C, Fabre C, Bart F, Grosbois JM, Berthoin S, Mucci P (2004) Evidence of exercise-induced arterial hypoxemia in prepubescent trained children. Pediatric Research 55: 647-68I.

Nourry C, Deruelle F, Guinhouya C, Baquet G, Fabre C, Bart F, Berthoin S, Mucci P (2005) High-intensity intermittent running training improves pulmonary function and alters exercise breathing pattern in children. European Journal of Applied Physiology 94: 415-423.

Obert P, Mandigouts S, Nottin S, Vinet A, N'Guyen LD, Lecoq AM (2003) Cardiovascular responses to endurance training in children: effect of gender. European Journal of Clinical Investigation 33: 199-208.

Obert P, Courteix D, Lecoq AM, Guenon P (1996) Effect of long-term intense swimming training on the upper body peak oxygen uptake of prepubertal girls. European Journal of Applied Physiology 73: 136-143.

Pate RR, Wang CY, Dowda M, Farrell SW, O'Neill JR (2006) Cardiorespiratory fitness levels among US youth 12 to 19 years of age - Findings from the 1999-2002 
National Health and Nutrition Examination Survey. Archives of Pediatrics and Adolescents Medicine 160: 1005-1012.

Plank DM, Hipp MJ, Mahon AD. (2005) Aerobic exercise adaptations in trained adolescent runners following a season of cross-country training. Research in Sports Medicine 13: 273-286.

Powers SK, Howley ET (2003) Exercise physiology, theory and applications to fitness and performance, $5^{\text {th }}$ edition. New York: McGraw-Hill.

Rowland T, Goff D, Martel L, Ferrone L (2000) Influence of cardiac functional capacity on gender differences in maximal oxygen uptake in children. Chest 1 17: 629-635

Rowland TW (1993) Does peak VO2 reflect VO2-max in children - evidence from supramaximal testing, Medicine and Science in Sports and Exercise 25: 689-693

Rowland TW (1996) Developmental exercise physiology. Human Kinetics., Champaign, Illinois.

Rowland TW, Boyajian A (1995) Aerobic response to endurance exercise training in children. Pediatrics 96: 654-658.

Rowland TW, Martel P, Vanderburgh T, Charkoudian N (1996) The influence of short-term aerobic training on blood lipids in healthy 10-12 year old children. International Journal of Sports Medicine 17: 487-492.

Stansky AW, Mickelson RJ, Van Fleet C (1979) Effects of swimming training regimen on hematological, cardiorespiratory, and body composition changes in young females. Journal of Sports Medicine and Physical Fitness 19: 347-354.

Stoedefalke K, Armstrong N, Kirby BJ, Welsman JR (2000) Effect of training on peak oxygen uptake and blood lipids in 13 to |4-year-old girls. Acta Paediatrica 89: 1290- 1294.

Thevenet D, Tardieu-Berger M, Berthoin S, Prioux J (2007) Influence of recovery mode (passive vs. active) on time spent at maximal oxygen uptake during an intermittent session in young and endurance-trained athletes. European Journal of Applied Physiology 99: 133-142.

Thompson AM, Baxter-Jones ADG (2002) Endurance training in young female athletes. Sports Medicine and Arthroscopy Review 10: 33-4I.

Tolfrey K, Campbell IG, Batterham AM (1998) Aerobic trainability of prepubertal boys and girls. Pediatric Exercise Science I0: 248-263.

Tolfrey K, Barker A, Thom JM, Morse Cl, Narici MV, Batterham AM (2006) Scaling of maximal oxygen uptake by lower leg muscle volume in boys and men. Journal of Applied Physiology, 100: 1851-1856.

Vamvakoudis E, Vrabas IS, Galazoulas C, Stefanidis P, Metaxas TI, Mandroukas K (2007). Effects of basketball training on maximal oxygen uptake, muscle strength, and joint mobility in young basketball players. Journal of Strength and Conditioning Research 21: 930-936

Vehrs PR, Keller DM, George JD, Hager RL, Fellingham GW (2007) Monitoring VO2max during fourteen weeks of endurance training using the CardioCoach. Journal of Strength and Conditioning Research 21: 62-66.

Vinet A, Mandigout W, Nottin W, N'Guyen LD, Lecoq AM, Courteix D, Obert P (2003) Influence of body composition, hemoglobin concentration, and cardiac size and function of gender differences in maximal oxygen uptake in prepubertal children. Chest 124: 1494- 4999.

Williams CA, Armstrong N, Powell J (2000) Aerobic responses of prepubertal boys to two modes of training. British Journal of Sports Medicine 34 : I68- 173. 